\title{
Disturbance Automated Reference Toolset (DART): Assessing patterns in ecological recovery from energy development on the Colorado Plateau
}

Travis W. Nauman ${ }^{1}$, Michael C Duniway ${ }^{1}$, Miguel L Villarreal ${ }^{2}$, Travis B. Poitras ${ }^{2}$

1 U.S. Geological Survey, Southwest Biological Science Center, 2290 SW Resource Blvd, Moab, UT 84532

2 U.S. Geological Survey, Western Geographic Science Center, 345 Middlefield Rd MS \#531, Menlo Park, CA 94025

Corresponding Author: T.W. Nauman, tnauman@usgs.gov, 001-520-664-5597 


\section{Abstract}

A new disturbance automated reference toolset (DART) was developed to monitor

3 human land surface impacts using soil-type and ecological context. DART identifies reference

4 areas with similar soils, topography, and geology; and compares the disturbance condition to the

5 reference area condition using a quantile-based approach based on a satellite vegetation index.

6 DART was able to represent 26-55\% of variation of relative differences in bare ground and 26-

$741 \%$ of variation in total foliar cover when comparing sites with nearby ecological reference

8 areas using the Soil Adjusted Total Vegetation Index (SATVI). Assessment of ecological

9 recovery at oil and gas pads on the Colorado Plateau with DART revealed that more than half of well-pads were below the 25th percentile of reference areas. Machine learning trend analysis of

11 poorly recovering well-pads (quantile < 0.23) had out-of-bag error rates between 37-40\%

12 indicating moderate association with environmental and management variables hypothesized to

13 influence recovery. Well-pads in grasslands (median quantile [MQ] = 13\%), blackbrush

14 (Coleogyne ramosissima) shrublands (MQ =18\%), arid canyon complexes (MQ = 18\%), warmer

15 areas with more summer-dominated precipitation, and state administered areas $(\mathrm{MQ}=12 \%)$ had

16 low recovery rates. Results showcase the usefulness of DART for assessing discrete surface land

17 disturbances, and highlight the need for more targeted rehabilitation efforts at oil and gas well-

18 pads in the arid southwest US.

\subsection{Keywords}

Land rehabilitation, ecological reference, energy development, digital soil mapping, remote sensing

\section{Introduction}

Assessing patterns in recovery from disturbance requires information on ecological context, which is commonly based on some approximation of reference condition (SER, 2004). Reference areas can help to estimate the pre-disturbance condition of a discrete disturbance such as an oil or gas well-pad. Once comparable sites with similar ecological potential are identified, recovery over time can be assessed against those reference areas. Reference sites should be nearby to a disturbance, as to have roughly equivalent climate and management histories, with 
the only difference being the actual human impacts of interest (as is done in disturbance assessment field studies; e.g. Duniway et al., 2010b).

The fields of digital soil mapping (DSM) (Grunwald et al., 2011; McBratney et al., 2003; Mulder et al., 2016; Scull et al., 2003) and predictive ecological modeling (PEM) (Chee et al., 2016; Elith et al., 2010; Guisan and Zimmermann, 2000; MacMillan et al., 2007) offer a wide range of geographic tools for creating both a spatial and thematic linkage between field sites for reference identification and critical zone assessment (Bui, 2016). This relates well to state-factor theory popularized in soil science by Hans Jenny (1941), which was later formalized into an human-ecosystem level state factor model (Amundson and Jenny, 1991; Amundson and Jenny, 1997; Jenny, 1961; Jenny, 1980). State-factor theory indicates soil-geomorphic variation can constrain local variation in 'ecological reference' areas with similar soils, geomorphic setting, and climate. Reference areas can be compared to a disturbance using remotely sensed vegetation index to get a general understanding of vegetation recovery. The goal of the research presented here is to develop a disturbance automated reference toolset (DART) suitable for the assessment of ecosystem recovery after oil and gas well-pad development or similar surface disturbances.

\subsection{Oil and Gas Disturbance Trends}




\subsection{Well-pad rehabilitation and policy}

It is unclear how long well-pad footprint disturbances persist on the landscape once wellpads are decommissioned, particularly in more arid regions. Active management intervention (rehabilitation hereafter) of vegetation and soils at decommissioned well-pads has become more common in recent years, but intensive reclamation is not standard practice and pads are often left to recover without rehabilitation (Bugden et al., 2016; Pedroni et al., 2013). Where rehabilitation requirements are specified in development permitting (as is done where National Environmental Policy Act [NEPA] applies) no comprehensive standards exist for defining rehabilitation success (Warner and Shapiro, 2013). The BLM Gold Book (USDOI and USDA, 2007), a frequently referenced Oil and Gas development standards book, outlines general standards for well-pad leveled, and removed soil is 'stockpiled' in a manner protected from wind and water erosion with topsoil separated from subsoil. Although the stated goal of rehabilitation ('reclamation' in Gold Book) is the 'pre-disturbance condition', the operator is only responsible for returning the site to an initial state of 'stability... so that no impediment exists that would prevent achieving the final goal (pre-disturbance condition)' (USDOI and USDA, 2007; pg 2; see also pp. 43-49).

Determining if a site has no impediment to returning to a pre-disturbance state after disturbance is a difficult judgment for even the most experienced natural resource professionals, especially in arid landscapes (Duniway et al., 2015; Miller et al., 2012; Webb, 2002). Thus, the Gold Book standards leave a considerable amount of discretion at the field level for determining that a drill operator has met their rehabilitation responsibility. In a study of long-term well-pad recovery after pad decommissioning, sagebrush shrublands had not fully re-established vegetation and soil conditions expected in those communities 47 years later (Minnick and Alward, 2015).

\subsection{Oil and Gas impacts on Colorado Plateau}

Oil and gas plays on the semi-arid Colorado Plateau of the southwestern USA are of particular concern because of the ecological sensitivity of the region to combinations of land use and climate uncertainty (Schwinning et al., 2008). With recent expansion of oil and gas development, potential for associated land-use conflicts, and the importance of the region in regulating dust transport for hydrological cycling (Neff et al., 2008; Painter et al., 2010), it is imperative to understand how recovery and rehabilitation of well-pads might affect future landuse sustainability. The extent of oil and gas development on the Plateau is immense -- currently 


\section{Methods} Plateau.

\subsection{Study Area}

state databases in Utah, Colorado, and New Mexico (COCG, 2015; GO-TECH, 2015; UAGRC, 2015a) contain 89,984 locational (x,y) records related to oil and gas exploration and development. Although this figure is daunting from a rehabilitation standpoint, remotely sensed indicators of impacts and recovery do hold promise for rapid assessment over large land areas (e.g. Allred et al. 2015). To address the broad scope and magnitude of assessing proliferating discrete disturbances like oil and gas pads, we propose a method to monitor spatial and temporal patterns of recovery in an automated fashion using remote sensing and soil-eco-geomorphic ecological potential mapping strategies. We applied this to the Plateau, but the application has potential for use in many areas globally.

\subsection{How do we contextualize well-pad recovery?}

We use location data for abandoned oil and gas pads within the DART framework to assess pad recovery using remotely sensed indicators of key dryland ecosystem functions (bare soil and perennial vegetation cover) (Pyke et al., 2002). Specifically, we use a soil map and large set of topography and satellite imagery variables to approximate what Elith et al. (2010) refer to as a multivariate environmental similarity surface to identify reference locations and gauge context specific well-pad recovery. This draws from DSM and PEM to identify areas of similar ecological potential and resilience to disturbance (Gunderson, 2000) to more effectively contextualize satellite based assessment of pad condition. This paper illustrates the application of DART to provide perspective on recovery of oil and gas well-sites. In field-based ecological potential grouping schemas like ecological sites (Caudle et al., 2013; NRCS, 2014), areas are often grouped by similar soils and geomorphology within geographically explicit climate zones. This same schema is locally approximated by DART using a new soil map of soil texture, rock content, and depth, and unsupervised classification datasets representing topographic and geologic variation to select reference areas (See Nauman and Duniway, 2016). DART enables comparison to reference areas to assess oil and gas well-pad recovery patterns on the Colorado

The Colorado Plateau is a distinctive region of mainly sedimentary lithological landscapes that have been uplifted to anywhere from 1200-2000 meters above sea level along 
with various laccoliths and volcanic districts that include mountains in excess of 3700 meters.

119 For our study area, we focused on the U.S. EPA's definition of the Colorado Plateau including parts of Arizona, New Mexico, Colorado, and Utah within the Colorado Plateau and Arizona and

121 New Mexico Plateaus units (EPA level three ecoregions 20 and 22; Omernik and Griffith, 2014,

122 Fig. 1). We refer to our study area for Fig. 1 as the 'Plateau' hereafter, and it encompasses a

123 large area $\left(366,000 \mathrm{~km}^{2}\right)$ across a broad spectrum of aridity, lithology, topography and seasonal

124 distribution of precipitation. Plateau ecosystems include arid and semi-arid shrublands and

125 grasslands, pinyon-juniper and scrub-oak woodlands, subalpine conifer systems, and alpine

126 tundra (Lowry et al., 2007). The majority of oil and gas wells on the Plateau are located in the

127 lower to mid elevation shrublands, grasslands and woodlands.

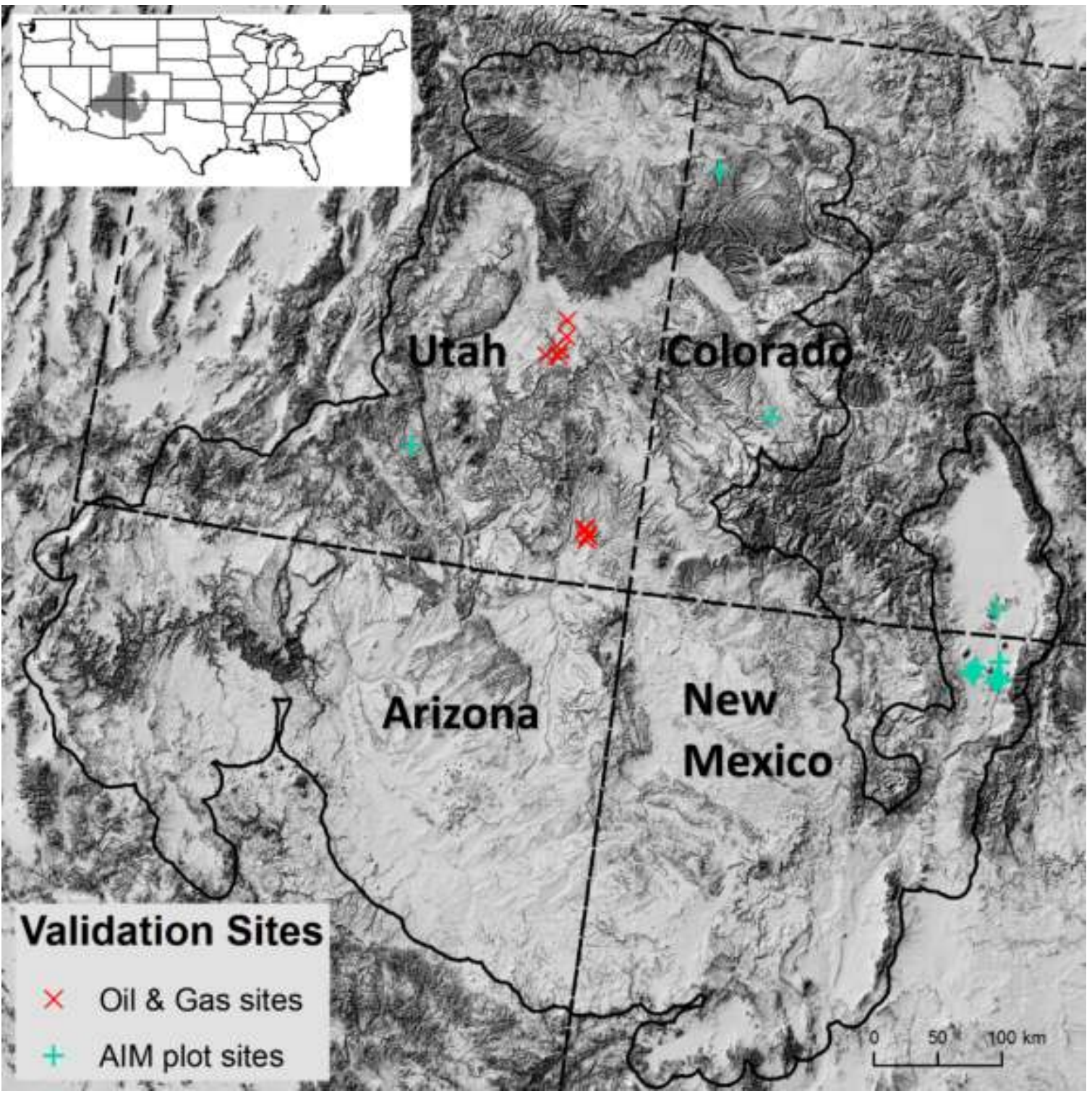


Fig. 1. Study area defined by $12 \mathrm{~km}$ buffer around the outer boundaries of EPA level 3 ecoregions 20 and 22 used for raster analysis (black outline). Inset map shows location of area within conterminous U.S.A. Also shown are the location of the DART validation sites. Sites included Bureau of Land Management Assessment Inventory and Monitoring (AIM) sites along with a set of recovering oil and gas pads visited in the field.

\subsection{Spatial Datasets}

Development of DART builds on a suite of environmental raster covariates with spatial coverage covering the entire Plateau following Nauman and Duniway (2016). These covariates were derived from the National Elevation Dataset (NED; Gesch, 2007; Gesch et al., 2002), Southwest ReGAP (SWREGAP; Lowry et al., 2007), 800m 1981-2010 PRISM climate dataset (PRISM Group, 2010) resampled to 30m by cubic convolution, National Renewable Energy Lab wind potential layer (NREL, 2015), National Land Cover Database (NLCD) (Homer et al., 2015), and a USGS Landsat 8 top-of-atmosphere composite (L8TOA) following Nauman and Duniway (2016). Topographic analysis was performed in SAGA GIS (Conrad and Wichmann, 2011). Flow accumulation was computed using the Dinf algorithm (Tarboton, 1997), and landform elements were derived following Schmidt and Hewitt (2004). Layers included the automated reference toolset (ART) suite of topographic (TOPO) and Landsat (LS) geologic indices to represent local soil-geomorphic variability and screening layers to exclude developed lands from comparisons (App. A; Nauman and Duniway, 2016). All computing was done on a windows-based eight-core desktop computer with 16 gigabytes of RAM.

Data on oil and gas well-pad location and status were acquired from three publically available state-level databases. The Utah data were obtained from the Utah Automated Geographic Reference Center (UAGRC, 2015a); New Mexico data from The New Mexico Institute of Mining and Technology's Petroleum Recovery Research Center (GO-TECH, 2015); and the Colorado data from The Colorado Oil and Gas Conservation Commission (COCG, 2015). In total we obtained 89,984 locations for the three combined states spanning from the early 1900s through 2015 which we then mapped in ArcGIS. There were 629 oil and gas development records on the Arizona portion of the Plateau, and due to their small number and lower level of attribution, the Arizona wells were left out of this analysis. 
For Utah, Colorado and New Mexico, we then filtered out well-pad locations by year, well-pad status and land cover type, removing developed and agriculture land and only keeping locations with a status of "plugged and abandoned" from 1997-2005 to check using Google Earth Pro historical aerial imagery dataset to determine if well-pad points corresponded to a visible well-pad disturbance when in production. Through the visual inspection process we were able to remove well-pad points that were either duplicates, still visibly active in 2015, non-existent, or currently within an urban/commercial or agricultural land development. In addition, we found that many of the original point locations had geo-referencing errors, for these locations we were able to move the point onto into the center of the discernable pad. Once the visual inspections were complete, we were left with a total of 1,866 validated well-pad locations: 481 in Utah, 399 in Colorado and 986 in New Mexico.

Road GIS databases were used to screen out pixels that contain roads for selecting reference. For all states, U.S. Census Bureau - Geography Division Tiger Lines road files (USCB-GD, 2015) were downloaded by county. In Utah and Colorado, supplemental roads layers were downloaded (CDOT, 2015 - downloaded "Highways", "Local Roads", "Major Roads" and "Routes"; UAGRC, 2015b). These layers were then rasterized from buffers created by road type following Nauman and Duniway (2016).

\subsection{Disturbance Automated Reference Tool (DART) Process}

The DART process aims to identify areas of similar ecological potential (referred to as "reference" hereafter) to compare with a recovering land surface disturbance. To do this, DART builds on the ART framework (Nauman and Duniway, 2016) identification of areas with similar soil and geomorphic setting within a specified distance of a well-pad footprint for comparison. We assume that general climate patterns, management, and site pressures will be relatively similar nearby, thus isolating the oil or gas well-pad disturbance impact. Conceptually, this follows the ecological site framework where soil texture, soil chemistry, soil depth, rock content, and microclimates need to be constrained for reference choice (Briske et al., 2005; Caudle et al., 2013; Duniway et al., 2010a). For this, a map of soil particle size in the control section (PSCS), local topographical (TOPO) clusters, and local Landsat (LS) geological clusters were created for each well-pad to constrain areas of similar potential (Fig. 2, App. A, Nauman and Duniway, 2016). Nauman and Duniway (2016) found the map of soil PSCS to be the most important 
component of identifying ecological reference areas. The PSCS map summarizes general soil texture and elements of soil depth and mineralogy into 20 classes for the CO Plateau. The neighborhood pixels that match the PSCS, TOPO, and LS classes with the values at the well-pad are designated as reference areas and used for comparison using a vegetation index (Fig. 2). The number of pixels selected for reference at well-pads was summarized and tested for biasing influence on well-pad recovery pattern analyses described in section 3.6. Pads with less than eight reference pixels were excluded from analysis.

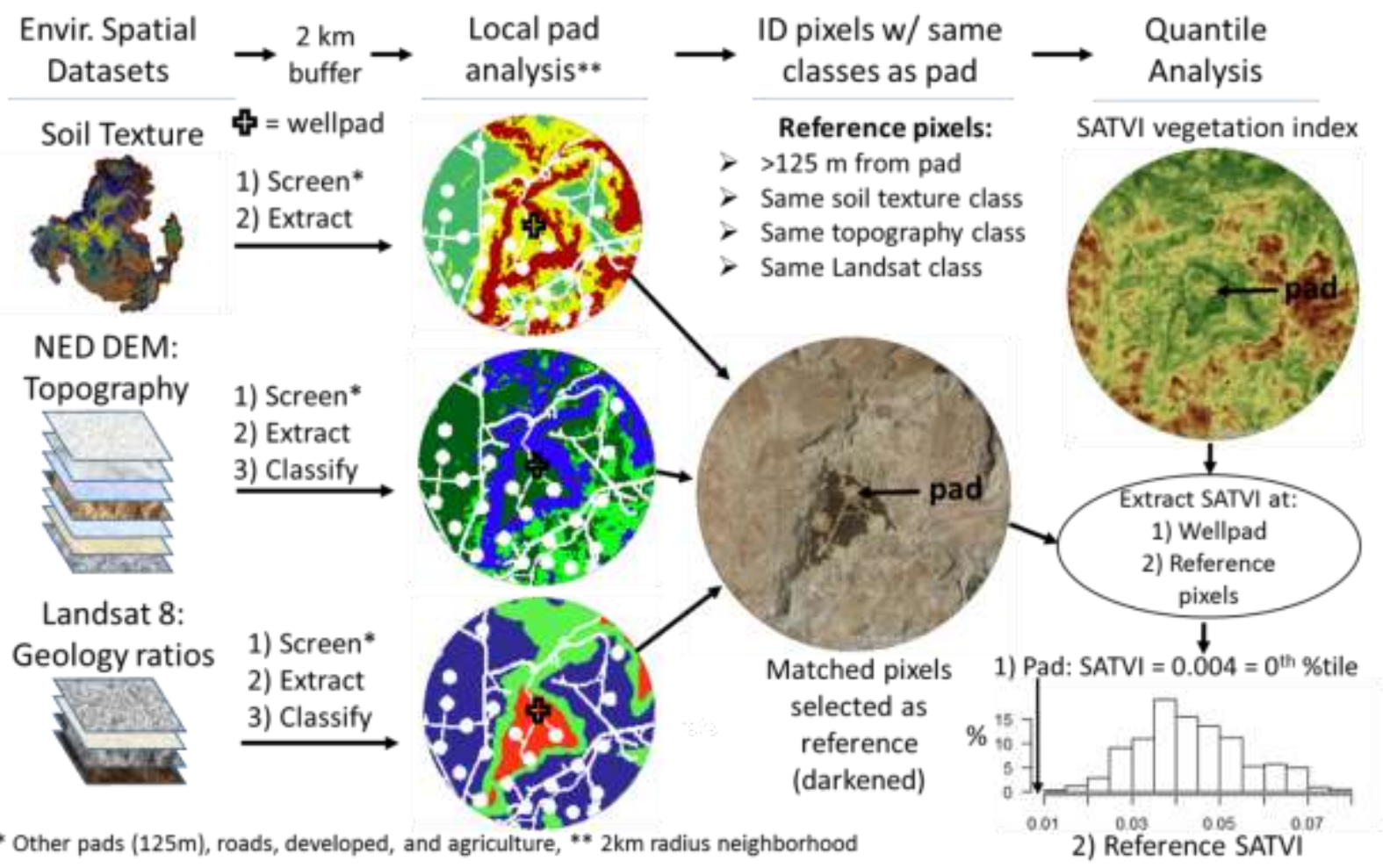

Fig. 2. Disturbance Automated Reference Toolset (DART) process chart. DART picks pixels for reference to compare soil adjusted total vegetation (SATVI) index values of the reference areas to that of a disturbance such as an oil or gas well-pad.

\subsection{Remote Sensing Recovery Indicator}

The Soil Adjusted Total Vegetation Index (SATVI, Marsett et al., 2006; Qi et al., 2002) was used as an indicator of vegetation cover to compare disturbed and undisturbed sites. SATVI, a mid- and shortwave- infrared-based index that corresponds with both live and senescent vegetation cover, has been shown to predict vegetation cover more effectively than 
other vegetation indices in semi-arid rangeland environments (Goirán et al., 2012; Hagen et al., 2012; Marsett et al., 2006; Villarreal et al., 2016). SATVI exploits SWIR absorption of senescent vegetation, offering a relatively consistent measure of perennial vegetation cover irrespective of plant phenological cycles and therefore a more accurate and consistent measure of recovery. SATVI was calculated in Google Earth Engine from the L8TOA collection (Google Earth Engine Team, 2015; USGS, 2016) from median reflectance values between 5/15-9/30 of 2014 for well-pads and 2013-2015 for validation sites (to match measurement date) to get at a mid-green period of the growing season aimed at highlighting perennial vegetation (App. B). The soil-line adjustment slope was adjusted from its usual value of 0.5 (Huete, 1988) up to 0.9 based on more recent monitoring data results (Peters et al., 2015). SATVI values at each wellpad center pixel were compared with the distribution of the reference pixels' SATVI values identified for that pad by the DART process (Fig. 2). We chose the quantile of the well-pad SATVI value relative to the distribution of reference pixels' SATVI values as our recovery metric (e.g. 0.25 quantile indicates $75 \%$ of the reference pixels have a greater SATVI value than that of the pad). The quantile values of each well-pad are assumed to be an index of well-pad recovery relative to comparable local reference conditions, and we refer to this response variable as a 'recovery quantile' throughout the rest of this paper.

\subsection{Validation of DART}

We tested the ability of the DART process to 1) evaluate recovery of abandoned oil and gas disturbances using a field dataset ( $n=10$, Fig. 1) comparing well-pad condition to expert identified paired reference areas and 2) compare status of field vegetation plots from the Bureau of Land Management (BLM) Assessment Inventory and Monitoring (AIM, USDI-BLM, 2016) program where spatially clustered data were available (n=22, Fig. 1). All AIM plots with neighboring plots within $2 \mathrm{~km}$ were tested. If at least two neighbors fell into pixels identified as reference by DART, then the differences between total foliar cover and exposed bare ground (via line-point-intercept) at the plots in reference pixels were compared with the value at the central plot to look for correlations with DART quantile values. Relative total foliar cover (See Eq. 1) was expected to negatively correlate with quantiles (i.e. when neighboring reference plots have more cover the quantile should be lower). Conversely, relative bare ground was expected to correlate positively with quantiles because higher bare ground at neighboring plots would indicate that the central plot is in better condition and thus have a higher quantile. 
Reference areas for each oil and gas pad were chosen by a trained soil scientist to represent soil and landscape conditions similar to that of the pad prior to development, and in conditions broadly representative of the local management (e.g. reference sites were not located in areas that had abnormally high or low livestock use). At both well-pad and reference sites, soils were characterized, sites classified to ecological site, and ocular basal estimates of soil and plant cover (bare ground, litter, biological soil crust, rock, non-vascular, woody plants, forbs, grasslike) were collected within 5 meter radii of 1-3 locations. The well-pads were all in blackbrush (Coleogyne ramosissima) shrublands in San Juan and Grand County UT, and ranged in plug date (year when the oil or gas well went out of production and was capped off) from 1958 to 2010 . DART was run at these sites to test if relative differences in bare ground and plant basal cover collected in the field correlated with the recovery quantiles produced by DART. Cover parameters were compared by taking relative differences of the reference and pad parameters $[\mathrm{Eq} 1]$.

Eq. 1 Relative Cover $=(\operatorname{Avg}($ Reference Cover\% $)-$ Target Cover\% $) /($ Avg $($ Reference Cover\% $)$ + Target Cover\%)

These relative measures of cover were tested for correlations with DART recovery quantiles in the R statistical programing language (R Core Development Team, 2008).

\subsection{Analysis of oil and gas well-pad recovery patterns}

Recovery of oil and gas pads, as estimated by the DART recovery quantile, was compared with a suite of variables hypothesized to influence recovery (Table 1). These included regional climate parameters, biophysical classifications, topographical parameters, signs of active rehabilitation in high resolution Google imagery, and land ownership/management. Land ownership GIS databases were downloaded for Utah, New Mexico, and Colorado to look at potential variations in recovery difference within different administrative regimes. Colorado data was obtained from the Bureau of Land Management (BLM) Colorado State Office Geosciences Team (BLM-CO-GT, 2015). New Mexico (NM) land ownership data was obtained from the University of New Mexico Gstore website, but was produced by the NM BLM (BLM-NM-SO, 2014). Utah land ownership data was downloaded from the UAGRC website, but is maintained jointly by the Utah School and Institutional Trust Lands Administration (SITLA) and BLM (SITLA-BLM, 2015). Recovery variables were tested using a variety of analytical tools to ensure 
266 (KT) correlation tests (Kendall, 1938), 2) Kruskal-Wallis (KW) rank sum tests (Kruskal and

267 Wallis, 1952), 3) random forest (RF) (Breiman, 2001; using classification setting defaults in

268 randomForest package; Liaw \& Wiener, 2002), and a 4) classification tree (CT) (Breiman,

269 1984). In all these methods, the variables in Table 1 were tested for association with variation in

270 the recovery quantile. The RF was used as a broad test of variable importance that allows for

271 non-linear and interacting relationships to be evaluated in a systematic fashion that is somewhat

272 robust to dimensionality and collinearity (Dormann et al., 2013; Biau, 2012; Lunetta et al.,

273 2004). Only one pair of variables, annual precipitation (ppt_ann) and aridity index (AI) showed

274 strong correlation $r>0.7\left(R^{2}=0.98\right)$. However, with the large sample size and moderate number

275 of predictors (20), this correlation had very minimal effects on the results (accuracy, variable

276 importance and tree breaks) when both RF and CT models were re-run excluding each variable.

277 This confirms recent conclusions of RF models being moderately robust to collinearity

278 (Dormann et al., 2013). Despite the strong correlation between AI and ppt_ann, we expected the

279 inclusion of potential evapotranspiration in the AI variable might provide some additional, if

280 subtle information about patterns of recovery.

281 Table 1

282 Analysis variables hypothesized to influence trends in well-pad recovery.

\begin{tabular}{|l|l|}
\hline Symbol & Description \\
\hline Al & Aridity Index (Maestre et al., 2012) from PRISM data using Thornthwaite PET (Thornthwaite, 1948) \\
\hline Landform & Topographic land element classification using DEM (Schmidt and Hewitt, 2004) \\
\hline ppt_ratio & PRISM ratio of summer precipitation (June-September) to total annual precipitation \\
\hline slope & Slope gradient in degrees calculated from DEM \\
\hline ppt_ann & Mean annual precipitation (mm) from PRISM normals (PRISM Group, 2010) \\
\hline temp_ann & Mean annual temperature (deg C) from PRISM normal (PRISM Group, 2010) \\
\hline regap_veg & Generalized classes from the Southwest ReGAP dataset (Lowry et al., 2007, See App. C for details) \\
\hline Soil_PS & Predicted soil particle size in the control section (defined in: Soil Survey Staff, 2010). \\
\hline EPA_L4 & Environmental Protection Agency level 4 ecological units (Omernik and Griffith, 2014). \\
\hline NLCDcl & National Land Cover Database (NLCD) classes (Homer et al., 2015). \\
\hline Plug_YR & Year each well-pad was plugged. Pulled from the state Oil and Gas databases. \\
\hline Sness & index from 1 to -1 of how south (1) or north (-1) a site faces \\
\hline NWness & index from 1 to -1 of how northwest (1) or southeast (-1) a site faces \\
\hline SWness & index from 1 to -1 of how southwest (1) or northeast (-1) a site faces \\
\hline Wness & index from 1 to -1 of how west (1) or east (-1) a site faces \\
\hline TWI & Topographic wetness index aka compound topographic index (Yang et al., 2007). \\
\hline Protlndex & Protection Index of surrounding topography in SAGA GIS \\
\hline gov_own & General land ownership for each well-pad from state GIS databases. \\
\hline profile_curv & Profile curvature calculated from DEM in SAGA GIS. \\
\hline
\end{tabular}


\begin{tabular}{|l|l} 
Restoratio & $\mathrm{Y} / \mathrm{N}$ Evidence of rehabilitation observation in Google Earth Pro
\end{tabular}

283

Bivariate tests ( $\mathrm{KW}$ and $\mathrm{KT}$ ) were performed on the recovery quantiles to look for

285

286

287

288

289

290

291

292

293

294

295

296

297

298

299

300

301

302

303

304

305

306

associations. Both are non-parametric tests suitable for the highly skewed DART recovery quantile distributions observed. KT tests were only performed on numeric variables. KW tests were performed for both categorical and numeric variables. For numeric covariates, 10-classes of equal sample size were created to convert variables to nominal scale for input into the $\mathrm{KW}$ test. The KW test of numeric variables helps look for non-linear relationships (e.g. hot or cool spots). All analysis of recovery was performed in the R Statistical Programing package (R Core Development Team 2008)

Given the coarse nature of satellite-based indicators of ecosystem properties (including SATVI, 30m resolution), the lack of differentiation between desirable native and undesirable non-native species (e.g. Bromus tectorum and Salsola spp.), and other factors infusing noise into the recovery quantile response indicator, we elected to split the data into 'low' recovery and 'high' recovery classes for parts of the analysis. The premise of this classification was to focus on differentiating factors that may cause very poor recovery and limit spurious relationships. We used a sensitivity analysis with the random forest to see which recovery quantile value for differentiating 'low' and 'high' would provide balanced out-of-bag class errors in order to get the best inference into controls on the variation. This optimized binary random forest, along with the $\mathrm{KT}$ and $\mathrm{KW}$ tests on recovery quantile variation, were then used to help guide selection of variables for building a pruned classification tree (CT) to help understand how covariates were influencing recovery at the 'high' versus 'low' recovery well-pads. The CT was pruned following Breiman (1984) by building the largest possible tree and then pruning back to an optimal complexity parameter optimized using 10 -fold cross validation error rates using the rpart module in R (Therneau et al., 2010). 


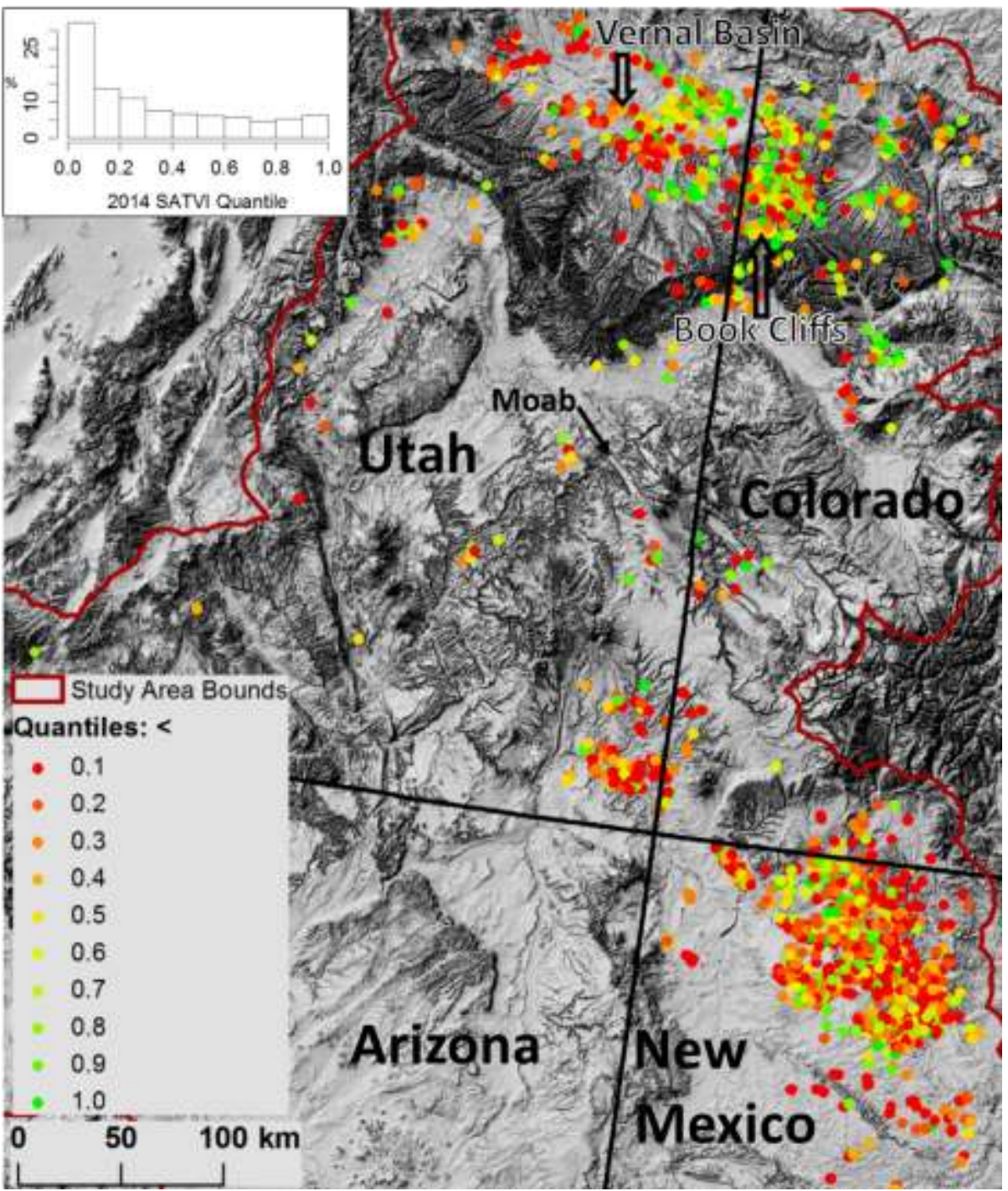

309 Fig. 3. Spatial distribution and histogram (upper left) of well-pad recovery quantiles centered on

310 the four corners region of the US. Points in red have lower vegetation cover signal while those in

311 green have higher cover relative to reference areas. The distribution of quantiles is highly

312 skewed right suggesting a significant portion of well-pads have recovered very little relative to 313 reference areas.

The distribution of well-pad recovery quantiles were highly right skewed with half of the 315 pads showing poor recovery (recovery quantile less than 23\%; Fig. 3). Visual inspection of the 316 spatial pattern suggests pads are recovering less in New Mexico and southeastern Utah.

317 Recovery patterns appear better farther north along the Utah-Colorado border on the Book Cliffs 
Plateau. West of the Book Cliffs in the Vernal basin, recovery also appears less successful (Fig. 3). Number of pixels selected as reference for each well-pad varied from one to 5543 with a mean of 946, median of 728, and interquartile range of 370 to 1337. Eight well-pads had less than eight pixels selected as reference, leaving 1858 well-pads for analysis.

\subsection{Field Validation}

At AIM plots, DART recovery quantiles correlated moderately with both relative exposed bare ground (BG) and total foliar cover (TFC). We examined these correlations at plots that had at least two neighboring reference plots and found significant correlations between recovery quantile and cover parameters confirming DART detection of site status (TFG: $r$ = $0.51, p=0.015 ; \mathrm{BG} \mathrm{r}=0.51, \mathrm{p}=0.015, \mathrm{n}=22$, Fig. 4). Correlations were higher for plots with at least three neighboring reference plots (TFG: $r=-0.64, p=0.017$, BG: $r=0.56, p=0.045 ; n=13$ ) probably due to better representation of the reference pixel SATVI distribution.

At oil and gas pads examined, recovery quantiles relate best with basal bare ground differences between reference and oil and gas well-pad observations $(r=0.74, p=0.013$, Fig. 4). No significant correlations were found with well-pad vegetation basal cover parameters, but both total vegetation basal cover and perennial basal vegetation cover differences showed slight negative trends with recovery quantiles, similar to what would be expected. High intensity Salsola invasions were seen at four sites often dominating well-pad vegetation cover. Salsola is quite transient and might not be consistently reflected in the multi-month SATVI composite used for recovery quantiles. The higher outlier at recovery quantile $\sim 0.36$ (Fig. $4 \mathrm{c}$ ) was a well-pad where $47 \%$ of the soil cover was recorded as light cyanobacterial soil crust, which is a subtle distinction from bare ground and may be an explanation for the higher than expected relative bare ground difference. The distribution of recovery quantiles at these pads was much more balanced than the broader skewed set observed from 1997-2005 for the Plateau-wide analysis possibly reflecting the greater range of plug dates. 

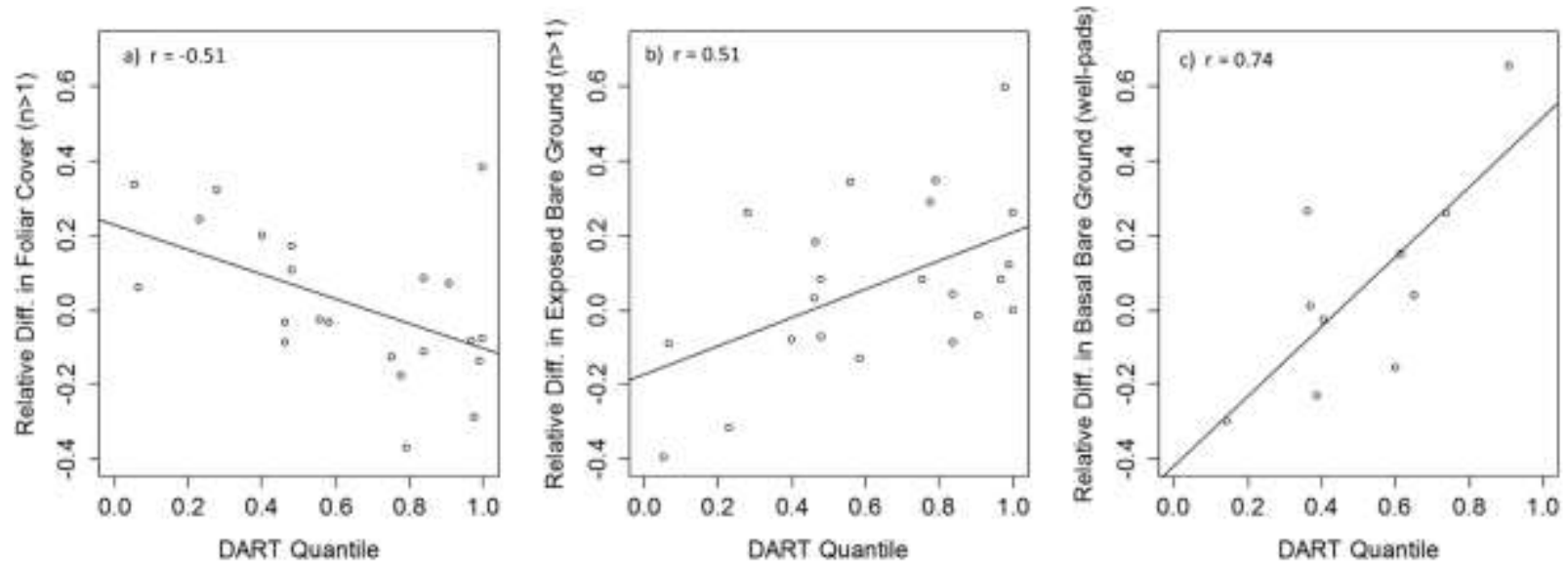

Fig. 4. Field comparisons of relative differences of bare ground and foliar cover to DART quantiles from SATVI. Parts a) and b) were derived from BLM-AIM data, and part c) is from oil and gas well-pad data.

\subsection{Random Forest Variable Importance}

Climate gradients and biophysical groupings explained the most variation between 'low' $\left(<22^{\text {nd }}\right.$ recovery quantile) recovery sites and 'high' recovery sites $\left(>22^{\text {nd }}\right.$ recovery quantile) when modeled with a random forest (Fig. 5). The model had an out-of-bag error of $37.1 \%$ with balanced errors between the high and low class. The Kappa test statistic of out-of-bag agreement was $0.257(\mathrm{p}<0.0001)$ indicating "fair agreement" (Cohen, 1960; Landis and Koch, 1977). The ratio of summer precipitation to mean annual precipitation (ppt_ratio) was the most important variable. The next most important variables were the EPA level four ecoregions (EPA_L4), generalized ReGAP (regap_veg) vegetation classes (see Appen. C for overview), and mean annual temperature (temp_ann). Land ownership (gov_own) also ranked highly followed by

357 annual precipitation (ppt_ann) and the aridity index (AI), below which a visible drop in 358 importance is evident (Fig. 5). The next grouping of variables that seem to be of intermediate 359 importance are dominated by topographical variables along with the national land cover 360 dababase (NLCDcl) and soil particle size in the control section (Soil_PS). Both the plug year 361 (Plug_YR) of the well-pad and the visible signs of rehabilitation (Restoratio) were some of the least important variables along with the different metrics of slope aspect. 

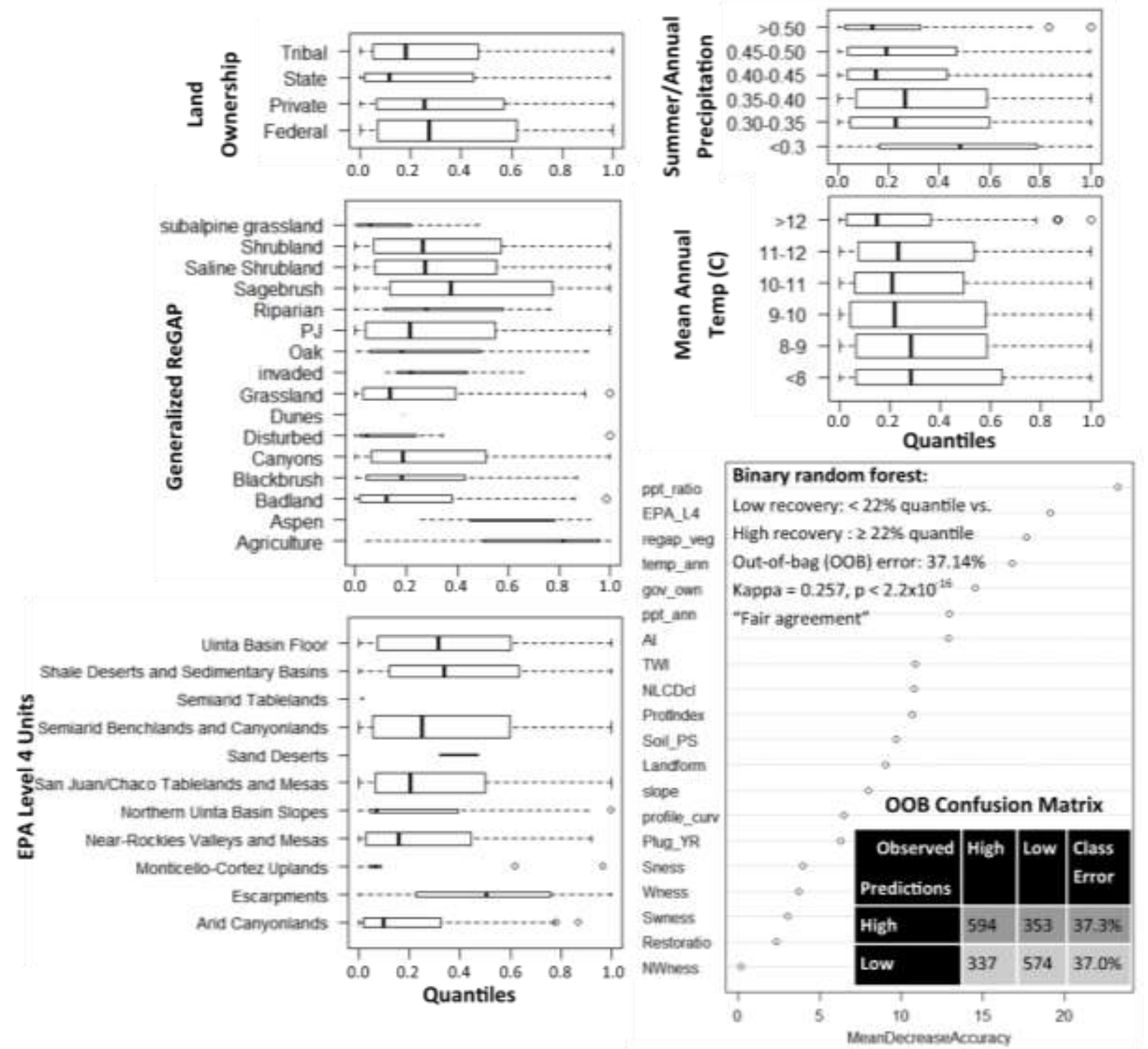

Fig. 5. Boxplots showing variation in well-pad recovery amongst most influential variables

366 identified in random forest (lower right). Boxplots are shown for each variable with vertical

367 width representing number of well-pads in each class. Random forest variable importance shows

368 variables with most influence on pad quantiles classified as low recovery (quantile <0.22) or

369 high recovery $(>0.22)$.

$370 \quad 4.3 \quad$ Bivariate Tests

371 The biophysical vegetation groupings (regap_veg and EPA_L4) and land ownership

372 (gov_own) showed the strongest abilities to discern recovery quantile differences in the bivariate

373 tests (Table 2). In comparing the Kruskal-Wallis (KW) sorted p-values to the random forest 
374 rankings, the trends are generally similar for the rest of the variables. Climate variables are not

375 quite as dominant in KW tests, whereas the topographical variables show a bit more association

376 with recovery quantiles. An interesting difference between $\mathrm{KW}$ p-values and the random forest is

377 the huge drop in the apparent association of ppt_ann with recovery quantiles. This could indicate

378 that ppt_ann tends to have relationships with well-pad recovery when nested within subsets of

379 some other variable.

$380 \quad$ Kendall's Tau (KT) correlation tests on numerical variables showed a similar sorting of

$381 \mathrm{p}$-values to the KW tests. Although six variables have p-values $<0.05$, none of the Tau values

382 exceed $|0.1|$, indicating that these are relatively subtle correlations. Higher proportions of

383 summer to annual precipitation were associated with lower recovery quantiles. Areas with

384 favorable topography for runoff wetness (high TWI values) and more adjacent higher and

385 sheltering topographic features (high ProtIndex) show association with higher recovery

386 quantiles. More concave (less convex) slope profile curvatures (higher profile_curv values) are

387 also associated with better recovery quantiles.

$388 \quad$ Table 2.

389 Variable tests for association or correlation with well-pad recovery quantiles. Includes Kruskal-

390 Wallis (KW) tests for differences between categorical groups and Kendall's Tau (KT) correlation

391 test. Variables are sorted by KW test p.value with most significant variables at top.

\begin{tabular}{|c|c|c|c|c|c|c|c|c|}
\hline Variable & $\begin{array}{c}\text { KW } \\
\text { ChiSq }\end{array}$ & $\begin{array}{r}K W \\
\text { df }\end{array}$ & KW p.value & $\begin{array}{l}\text { KT z- } \\
\text { score }\end{array}$ & KT p.value & $\begin{array}{c}\text { Kendall's } \\
\text { Tau }\end{array}$ & $\begin{array}{c}\text { KT } \\
\text { null.value }\end{array}$ & $\begin{array}{r}\text { KT alt } \\
\text { hypoth. }\end{array}$ \\
\hline regap_veg & 93.2 & 15 & $2.50 \mathrm{E}-13$ & na & na & na & na & na \\
\hline EPA_L4 & 61.8 & 10 & $1.66 \mathrm{E}-09$ & na & na & na & na & na \\
\hline gov_own & 28.6 & 3 & $2.71 \mathrm{E}-06$ & na & na & na & na & na \\
\hline ppt_ratio & 40.3 & 9 & $6.66 \mathrm{E}-06$ & -4.71 & $2.51 \mathrm{E}-06$ & -0.073 & 0 & two.sided \\
\hline $\mathrm{NLCDCl}$ & 38.8 & 10 & $2.74 \mathrm{E}-05$ & na & na & na & na & na \\
\hline TWI & 33.5 & 9 & $1.10 \mathrm{E}-04$ & 4.84 & $1.28 \mathrm{E}-06$ & 0.075 & 0 & two.sided \\
\hline temp_ann & 29.7 & 9 & $4.89 \mathrm{E}-04$ & -3.24 & $1.22 \mathrm{E}-03$ & -0.050 & 0 & two.sided \\
\hline ProtIndex & 23.3 & 9 & $5.62 E-03$ & 3.96 & $7.41 \mathrm{E}-05$ & 0.061 & 0 & two.sided \\
\hline Soil_PS & 19.8 & 8 & $1.12 \mathrm{E}-02$ & na & na & na & na & na \\
\hline $\mathrm{Al}$ & 21.2 & 9 & 1.19E-02 & 0.83 & 4.06E-01 & 0.013 & 0 & two.sided \\
\hline Landform & 21.7 & 10 & $1.66 \mathrm{E}-02$ & na & na & na & na & na \\
\hline profile_curv & 16.9 & 9 & $5.08 \mathrm{E}-02$ & -3.56 & $3.66 \mathrm{E}-04$ & -0.055 & 0 & two.sided \\
\hline Plug_YR & 14.9 & 8 & 6.07E-02 & -2.15 & $3.14 \mathrm{E}-02$ & -0.035 & 0 & two.sided \\
\hline Swness & 10.9 & 9 & $2.83 \mathrm{E}-01$ & 0.69 & $4.88 \mathrm{E}-01$ & 0.011 & 0 & two.sided \\
\hline Wness & 9.3 & 9 & 4.10E-01 & 0.72 & 4.72E-01 & 0.011 & 0 & two.sided \\
\hline slope & 8.7 & 9 & $4.62 \mathrm{E}-01$ & 0.18 & 8.59E-01 & 0.003 & 0 & two.sided \\
\hline Restoration & 0.50 & 1 & 4.81E-01 & na & na & na & na & na \\
\hline
\end{tabular}




\begin{tabular}{ccccccccc} 
ppt_ann & 7.9 & 9 & $5.48 \mathrm{E}-01$ & 1.11 & $2.68 \mathrm{E}-01$ & 0.017 & 0 & two.sided \\
Sness & 7.3 & 9 & $6.07 \mathrm{E}-01$ & 0.11 & $9.11 \mathrm{E}-01$ & 0.002 & 0 & two.sided \\
Nwness & 6.7 & 9 & $6.70 \mathrm{E}-01$ & 0.31 & $7.59 \mathrm{E}-01$ & 0.005 & 0 & two.sided \\
\hline
\end{tabular}

\subsection{Variable Influence Specificity and Directionality}

The random forest and bivariate test rankings of variable influence on well-pad recovery helped to narrow down the variables of interest to assess directionality. Subsets of the variables selected from these rankings were used to create plots (Fig. 5) and a Classification Tree

397 (App. D) to help understand how they influenced well-pad recovery. Generalized ReGAP

398 Grasslands, Badlands, and Canyons are the only extensively seen detailed biophysical classes with medians lower than the overall well-pad recovery quantile median, 0.23 . These ReGAP

400 classes tend to be in the southern and more arid parts of the Plateau. Areas with higher summer 401 precipitation ratios in the southern areas also have lower recovery quantiles with values dropping

402 below the Plateau median at about 40\% summer precipitation (June-Sept; Fig. 5). Mean annual 403 temperatures of greater than $12^{\circ} \mathrm{C}$ also have a noticeably lower recovery rate. State land 404 ownership status has the lowest well-pad recovery of the different ownership categories followed 405 by Tribal ownership. Federal and private ownership both have similar recovery quantile 406 distributions that are noticeably higher than State and Tribal (Fig. 5). Arid Canyonlands and 407 Near-Rockies Valleys and Mesas have the lowest median recovery quantiles amongst the EPA 408 level four ecoregions (Fig. 5).

\section{$409 \quad 4.5$ Classification Tree}

A classification tree was built to model the same binary break (recovery quantile of 0.22) used in the random forest. Explanatory variables were chosen firstly based on random 412 forest importance, secondly based on bivariate tests, and thirdly for representation of unique 413 information. Chosen variables included climate variables (ppt_ratio, temp_ann, AI, and 414 ppt_ann), biophysical classifications (EPA_L4, regap_veg, and NLCDcl), 415 management/ownership (gov_own), and soil/geomorphic variables (Soil_PS and TWI; Table 1). 416 The optimal cross-validated tree was large with 35 splits and had a 10-fold cross validation 417 accuracy of $60 \%$. Overall training agreement was $71 \%(\mathrm{Kappa}=0.424, \mathrm{p}<0.0001)$. A re418 creation of the model with the same code (different tree, although similarly structured) on a 
randomly selected $80 \%$ subset yielded a $59 \%$ agreement rate on the $20 \%$ test set (Kappa $=0.172$, $\mathrm{p}=0.0004)$.

The tree structure shows a complicated and nested set of breaks that mostly reflect the variable importance identified in the other analyses (App. D). The upper, and most important splits, are dominated by vegetation type (regap_veg) and the ratio of summer to total precipitation (ppt_ratio). These high splits show lower recovery in areas with higher ratios of summer precipitation (ppt_ratio) and in the vegetation classes with lower recovery quantile distributions in Fig. 5 (major classes including Badlands, Blackbrush, Canyons, Grasslands, and Pinon-Juniper). Common middle and lower tree splits include temp_ann, ppt_ann, EPA_L4, ownership (gov_own), Soil_PS and TWI.

\subsection{Number of Reference Pixels}

Variation in the number of reference pixels selected (npix) did subtly associate with quantile $(\mathrm{Tau}=-0.05, \mathrm{p}=0.0005)$, and all of the trend variables except plug year (Plug_YR), ownership (gov_own), SWness, and NWness, raising concern about bias. When added as a covariate to the random forest, npix ranked third to last in importance and slightly decreased accuracy, suggesting that it is not influential in quantile variation when accounting for other variables. New random forests were run with only pads that had more than 100 reference pixels (npix > 100; $\mathrm{n}=1746$ well-pads), with and without npix as a variable, and with npix switched in for summer precipitation ratio (ppt_ratio), with which it correlated with the most. From the pads with more than 100 npix, a new quantile was also calculated by randomly selecting 50 reference pixels and comparing to well-pad values. The new quantile was almost identical to the original $\left(\mathrm{R}^{2}=0.98\right)$ and produced an almost identical random forest model to the original in Fig. 5. Thus, all model iterations showed extremely similar variable importance rankings amongst explanatory variables and low variable importance of npix, all suggesting that npix variation was not biasing detected trends. A classification tree was also built with the same approach as App. D with npix included as a covariate to see if that would influence structure. The new tree was extremely similar and had the exact same biophysical (regap_veg) and summer precipitation ratio (ppt_ratio) breaks in the first two levels of the new tree as seen in App. D. The only influence of npix was in the third level of the tree where it replaced a regap_veg and a TWI rule. The accuracy of the new tree was also slightly lower (58.8\% 10-fold cross-validation). These results indicate that npix has a negligible biasing effect on the patterns detected in the analysis. 


\section{Discussion}

The disturbance automated reference toolset (DART) was able to effectively characterize general trends in well-pad recovery across the Colorado Plateau. DART results suggest relatively poor recovery of abandoned pads on the Plateau, with half of well-pads plugged from 1997-2005 having less soil cover (based on SATVI vegetation index values) than $77 \%$ of corresponding reference pixels. The year when a well-pad was plugged and abandoned was only weakly correlated to recovery quantile (Tau $=-0.035, \mathrm{p}=0.03, \mathrm{n}=1858)$ suggesting significantly more time may be needed for meaningful broad-scale temporal recovery trends to be observed. Due to the limited period of analysis (1997-2005), it's likely that not enough time lapsed for most of the well-pads to recover (Minnick and Alward, 2015). These results indicate many of the well-pads have been in a compromised state of bare ground exposure over extended timeframes (up to 17 years) that might put them at risk for ecosystem service impacts related to increased dust production (Li et al., 2013; Neff et al., 2008). Sites in the field validation older than 2000 generally did not exhibit signs of rehabilitation, and often had marked scarps left from well-pad leveling which may contribute to the longevity of these disturbances (Fig. 6, lower left).

Field validation showed DART is effective at characterizing trends in bare ground exposure and foliar canopy at well-pads. From this, identification of sites that are in particularly bad condition is possible due to the importance of these parameters in rangeland health (Pyke et al., 2002; Li et al., 2013). Despite validation results, it is possible that undesireable invasive plants (mainly Salsola spp. or Bromus tectorum on Plateau) could inflate quantile values from a single date or season computed vegetation index when assessing recovery to a desired condition. This issue may be addressed using combinations of seasonal recovery quantiles, following a similar methodology to regional Bromus tectorum mapping efforts (Boyte et al., 2015; Kokaly, 2011). The recovery quantile approach in DART makes it quite robust to outliers in the reference population, but very sensitive to the actual well-pad vegetation index value, hence careful selection of vegetation index timing and accurate spatial data is critical. However, the field results, and ability of the underlying ART framework to match locations to ecological site reference areas (Nauman and Duniway, 2016), indicate that DART is an effective tool for detecting broad trends, coarse-scale monitoring, and prioritization of sites for rehabilitation. 


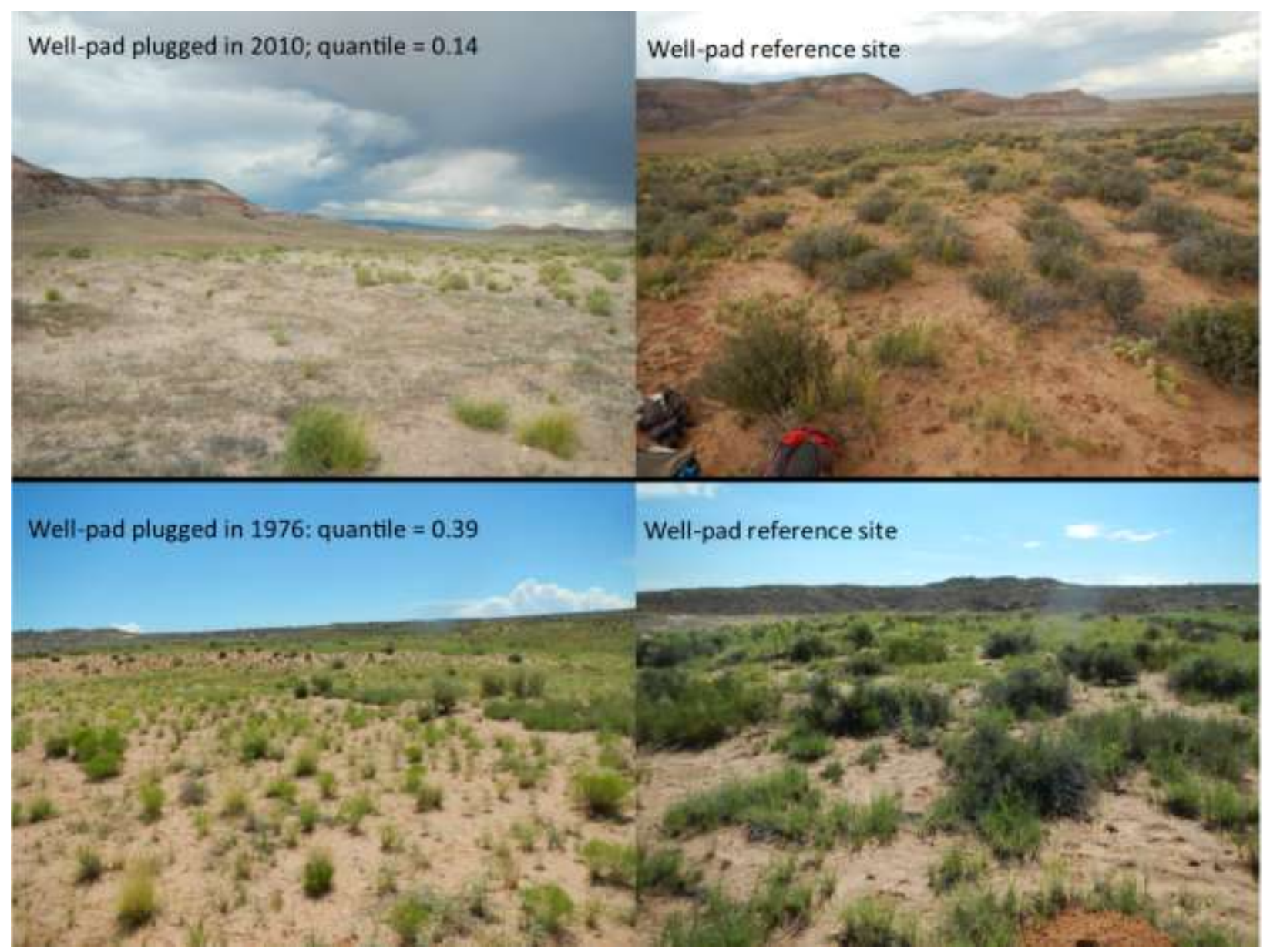

480 Figure 6. Photos taken in summer 2015 of well-pads (left) and corresponding reference sites 481 (right). Well-pads shown were plugged in 2010 (top) and 1976 (bottom).

\section{$482 \quad 5.1 \quad$ Applicability of DART}

483 Although application of DART in regions outside the Plateau will require developing the

484 PSCS layer, most other spatial datasets, or close equivalents, are readily available for many

485 locations globally. The Landsat remote sensing variables are available globally and can easily be

486 obtained from cloud services like Google Earth Engine, but may need to be modified for more

487 vegetated regions. Topographical data can be obtained from the Shuttle Radar Topographic

488 Mission for latitudes less than $|60|$ degrees (SRTM; Rodriguez et al., 2006). The NREL wind

489 potential layer is only available for the USA, but was not a very important layer in ART or

490 DART development. Both the southwest ReGAP (Lowry et al., 2007) and National Land Cover

491 Database (NLCD, Homer et al., 2015) are USA products that were used for screening out

492 developed areas in DART, but can be emulated for other areas of the world that do not have 
equivalents. Both ReGAP and NLCD were created using supervised classifications of remotely sensed data that could be recreated in regions without similar data products. Road maps are available globally (e.g. http://sedac.ciesin.columbia.edu/data/set/groads-global-roads-openaccess-v1/docs), but should be evaluated to determine if smaller rural dirt roads are included for use in the DART screening process.

Mapping of soil PSCS will be the main barrier to implementing DART off of the Plateau. However, the US Department of Agriculture - Natural Resources Conservation Service (USDANRCS) has a large repository of soil taxonomic field observations with almost 330,000 observations of PSCS around the world, but mostly in the USA. Mapping of PSCS should be attainable for other areas of the USA at 30-m resolution following the approach in Nauman \& Duniway (2016). Through efforts similar to SoilGrids (Hengl et al., 2017), PSCS maps could be produced globally, but this will require concerted effort, especially at 30-m resolution due to computational challenges (Chaney et al., 2015). Production at 100-m resolution might be more feasible, but will need to be tested to see if this still captures enough spatial detail for DART implementation.

Remote sensing vegetation indices that capture more variation in greenness (e.g. Normalized Difference Vegetation Index or the Enhanced Vegetation Index) and/or structure (e.g. Lidar) may be more appropriate than SATVI in wetter climates with more dense vegetation cover (e.g. Gao, 1996; Hilker et al., 2014; Hyyppä et al., 2000; Lim et al., 2003). Greenness indices can be calculated from Landsat, which is available globally, but more structural data sources like Lidar are still available only in limited areas. Field validation of DART with these alternative indices will be needed outside of arid and semi-arid regions.

\subsection{Trends in well-pad recovery}

Across all metrics, Southwest ReGAP vegetation classes (regap_veg), EPA Level four ecoregions (EPA_L4), and summer precipitation ratio (ppt_ratio) showed the strongest association with differences in recovery quantiles. Land ownership (gov_own) and mean annual temperature (temp_ann) also showed moderate and consistent associations with recovery in all analyses. Based on these multiple converging analyses, associations suggest that ecological resilience to oil and gas surface disturbance varies across biophysical environments, climate gradients, and land management regime on the Colorado Plateau. 
Canyon-dominated areas, shale badlands, and semi-arid grassland areas had lower recovery quantiles. The poor recovery of badlands was expected, given these areas are characterized by delicate and sparse vegetation communities on saline clayey shale soils (Flagg et al., 2014). However, the poor recovery of well-pads on grasslands was surprising as grass growth forms generally recolonize more readily than the woody species following severe disturbance (Duniway et al., 2015), but others have noted slow regional grassland recovery from grazing disturbance (Schwinning et al., 2008).

The Plateau encapsulates a wide range of seasonal precipitation distribution and temperature. Recovery quantile decreased with both higher summer precipitation ratio and higher mean annual temperatures. Regional studies have also shown that these climate variables influence soil water storage timing and amount in ways that can differentially influence plant growth and mortality depending on photosynthetic pathways (C3 versus $\mathrm{C} 4)$ (Comstock and Ehleringer, 1992; Gremer et al., 2015; Hereford and Webb, 1992; Hereford et al., 2002; Thoma et al., 2016; Witwicki et al., 2016). Soil water storage from cool-season events has been demonstrated as critical for C3 grass productivity on the Plateau (Gremer et al., 2015). However, the high inter-annual variability that characterizes summer monsoonal precipitation, combined with warmer temperatures and often high intensity precipitation can be problematic, particularly for C4 grasses (Witwicki et al., 2016); which necessitates new and innovative rehabilitation approaches (e.g. Fick et al., 2016). These results and studies warrant future investigation into seasonal moisture stress timing impacts on well-pad recovery.

Comparison of well-pad recovery among land ownership regimes indicated significantly less recovery on State and Tribal lands than those lands under Federal or private management (Table 2; Fig. 5). It is important to note that much Tribal land ownership is coincident with climate factors associated with poor recovery (warm temperatures and more summer precipitation). Federal, private, and state lands, however, are interspersed across the Plateau, making comparisons amongst them more valid. In particular, Federal and state lands occupy very similar spatial distributions due to the way state lands are "checker-boarded" in with Federal lands. The lower recovery of pads on state-managed parcels suggests that aspects of well-pad permitting, management, and/or rehabilitation on state lands (recovery quantile median $=0.12$ ) may be less successful in promoting well-pad recovery than those managed by Federal 
553 (recovery quantile median $=0.27)$ and private entities (recovery quantile median $=0.26)($ Table

554 2, Fig. 5). Given the potential for future well-pad development, further investigations that compare development and management practices that foster or suppress recovery may better facilitate better resource management success across all land holdings.

Well-pads where active rehabilitation practices were evident in aerial imagery did not show higher recovery quantile values than other sites. We postulate that the lack of association between rehabilitation signs and recovery quantile is due to the coarse methods used to assess rehabilitation practices. Also, our recording of rehabilitation (binary Yes or No in Google Earth Pro) did not account for important variation in how rehabilitation was implemented (no record of kind, effort, timing, etc.) and also likely included false negatives (recorded no rehabilitation when rehabilitation did occur).

There is also a significant portion of variation in well-pad status not accounted for in our suite of explanatory variables (Listed in Table 1). There are several potential sources of this unexplained variation, including: 1) DART detection of recovery patterns has limitations (e.g. confounding signal of invasive plant species), 2) variability in on-site well-pad practices during operations and/or rehabilitation practices, and/or 3) important variation in underlying biophysical variable(s) that are not represented by our explanatory variables. It is likely that a combination of these explanations are responsible for the unexplained variability in the recovery quantiles across the region.

\section{Conclusions}

The DART assessment of oil and gas well-pad recovery effectively detected pads that have excessive bare ground exposed or depressed foliar canopy cover relative to reference areas. Efforts tying other field observations to SATVI or other satellite derivatives may yield connections to further ecosystem services (e.g. dust, Li et al., 2013). As bare ground is a primary indicator of rangeland productivity and susceptibility to erosion, this makes the DART process attractive for fast and broad scale rehabilitation monitoring efforts, and especially powerful where DART could be augmented with on-the-ground monitoring (e.g. Duniway et al., 2012). Using the DART recovery quantile metric to represent well-pad recovery, we were able to discern that well-pads in grasslands, canyon complexes and shale badlands are not recovering as well as other ecotypes on the Colorado Plateau. Additionally, DART results suggest an important 
role of regional climate variation in mediating pad recovery. Higher summer precipitation proportion and higher mean annual temperatures were associated with poor well-pad recovery. Significant differences in well-pad recovery among land ownership groups suggest there is a role of land management in promoting or hampering pad recovery (in siting, development, and/or reclamation phases). Further refinement of the vegetation index timing used in DART might help account for seasonal invasive annuals (Boyte et al., 2015; Kokaly, 2011; Norton et al., 2004). However, without DART, these regional-scale patterns in well-pad recovery among vegetation types, climate, and land ownership might have gone on unnoticed -- demonstrating the value of DART to help monitor broad land use trends.

The DART approach demonstrated here has the potential to be transformative for institutions and agencies tasked with managing discrete disturbances across large landscapes. DART employs a unique combination of digital soil mapping tools, concepts of ecological potential, and a new remote sensing analysis platform. In addition to the remote sensing analysis implemented here, we expect DART also will be used in conjunction with field evaluations, such as optimizing sampling efforts to better understand the ecological processes controlling recovery, or to provide greater temporal resolution for existing field monitoring efforts. Landuse/land-cover change is a growing concern in dryland regions globally (Bestelmeyer et al., 2015), and recovery of these systems from intensive land-use activities will likely become more unpredictable with global climate change (Cook et al., 2015; Seager and Vecchi, 2010). More tools that can provide broad-scale assessments of the impact and recovery of land-use/land-cover change, such as the DART approach shown here, are needed to identify these growing threats.

\section{Acknowledgements}

Funding for this work was provided by the U.S. Geological Survey Priority Ecosystems Sciences Program and Ecosystem Mission Area. We thank Keith Crossman, Mark Miller, and Jamin Johanson for providing data and input on soil-ecological relationships. We acknowledge the work and persistence of the National Collaborative Soil Survey field soil scientists represented in the NASIS dataset, and thank the USDA-NRCS National Soil Survey - Geospatial Research Unit at West Virginia University for providing access to NASIS. We thank Sharon Waltman, Henry Ferguson, and Skye Wills for their guidance in working with the NASIS database snapshot. We also thank Brady Allred for guidance working with Google Earth Engine and the well-pad 
613 datasets. Use of trade, product, or firm names is for information purposes only and does not 614 constitute an endorsement by the U.S. Government.

615 


\section{References}

Allred, B. W., Smith, W. K., Twidwell, D., Haggerty, J. H., Running, S. W., Naugle, D. E., and Fuhlendorf, S. D., 2015, Ecosystem services lost to oil and gas in North America: Science, v. 348, no. 6233, p. 401-402.

Amundson, R., and Jenny, H., 1991, THE PLACE OF HUMANS IN THE STATE FACTOR THEORY OF ECOSYSTEMS AND THEIR SOILS: Soil Science, v. 151, no. 1, p. 99-109.

Amundson, R., and Jenny, H., 1997, On a State Factor Model of Ecosystems: BioScience, v. 47, no. 8, p. 536-543.

Bestelmeyer, B. T., Okin, G. S., Duniway, M. C., Archer, S. R., Sayre, N. F., Williamson, J. C., and Herrick, J. E., 2015, Desertification, land use, and the transformation of global drylands: Frontiers in Ecology and the Environment, v. 13, no. 1, p. 28-36.

Biau, G. (2012). Analysis of a random forests model. Journal of Machine Learning Research, 13, 10631095

BLM-CO-GT. 2015, BLM Colorado, Land Ownership/Surface Management Agency (http://www.blm.gov/co/st/en/BLM_Programs/geographical_sciences/gis/GeospatialData/Ist_c onflated_poly.print.html).

BLM-NM-SO. 2014, Bureau of Land Management Surface Land Ownership (NM) (http://gstore.unm.edu/apps/rgis/datasets/13ac7a34059c436fad5c8e0ed3e340b8/landown201 4.original.zip).

Boyte, S. P., Wylie, B. K., and Major, D. J., 2015, Mapping and monitoring cheatgrass dieoff in rangelands of the Northern Great Basin, USA: Rangeland Ecology and Management, v. 68, no. 1, p. 18-28.

Breiman, L., 1984, Classification and regression trees, Wadsworth International Group, 358 p.:

Breiman, 2001, Random Forests: Machine Learning, v. 45, no. 1, p. 5-32.

Briske, D. D., Fuhlendorf, S. D., and Smeins, F. E., 2005, State-and-transition models, thresholds, and rangeland health: A synthesis of ecological concepts and perspectives: Rangeland Ecology \& Management, v. 58, no. 1, p. 1-10.

Bugden, D., Kay, D., Glynn, R., and Stedman, R., 2016, The bundle below: Understanding unconventional oil and gas development through analysis of lease agreements: Energy Policy, v. 92, p. 214-219.

Bui, E. N., 2016, Data-driven Critical Zone science: A new paradigm: Science of The Total Environment.

Caudle, D., Sanchez, H., DiBenedetto, J., Talbot, C., and Karl, M., 2013, Interagency Ecological Site Handbook for Rangelands: USDA-NRCS, USDA-FS, \& DOI-BLM.

CDOT. 2015, Data Catalogue (http://dtdapps.coloradodot.info/otis/catalog).

Chaney, N.W., Wood, E.F., McBratney, A.B., Hempel, J.W., Nauman, T.W., Brungard, C.W., \& Odgers, N.P., 2016, POLARIS: A 30-meter probabilistic soil series map of the contiguous United States. Geoderma, 274, 54-67

Chee, Y. E., Wilkinson, L., Nicholson, A. E., Quintana-Ascencio, P. F., Fauth, J. E., Hall, D., Ponzio, K. J., and Rumpff, L., 2016, Modelling spatial and temporal changes with GIS and Spatial and Dynamic Bayesian Networks: Environmental Modelling \& Software, v. 82, p. 108-120.

COCG. 2015, Wells - http://cogcc.state.co.us/data2.html\#/downloads.

Cohen, J., 1960, A Coefficient of Agreement for Nominal Scales: Educational and Psychological Measurement, v. 20, no. 1, p. 37-46.

Comstock, J. P., and Ehleringer, J. R., 1992, Plant adaptation in the Great Basin and Colorado plateau: The Great Basin Naturalist, p. 195-215.

Conrad, O., and Wichmann, V., 2011, SAGA GIS (www.saga-gis.org): Hamburg, Germany.

Cook, B. I., Ault, T. R., and Smerdon, J. E., 2015, Unprecedented 21st century drought risk in the American Southwest and Central Plains: Science Advances, v. 1, no. 1, p. e1400082. 
Dormann, C. F., Elith, J., Bacher, S., Buchmann, C., Carl, G., Carré, G., Marquéz, J. R. G., Gruber, B., Lafourcade, B., and Leitão, P. J., 2013, Collinearity: a review of methods to deal with it and a simulation study evaluating their performance: Ecography, v. 36, no. 1, p. 27-46.

Duniway, M. C., Bestelmeyer, B. T., and Tugel, A., 2010a, Soil processes and properties that distinguish ecological sites and states: Rangelands, v. 32, no. 6, p. 9-15.

Duniway, M. C., Herrick, J. E., Pyke, D. A., and David, T. P., 2010b, Assessing transportation infrastructure impacts on rangelands: test of a standard rangeland assessment protocol: Rangeland Ecology \& Management, v. 63, no. 5, p. 524-536.

Duniway, M. C., Karl, J. W., Schrader, S., Baquera, N., and Herrick, J. E., 2012, Rangeland and pasture monitoring: an approach to interpretation of high-resolution imagery focused on observer calibration for repeatability: Environmental monitoring and assessment, v. 184, no. 6, p. 37893804.

Duniway, M. C., Palmquist, E., and Miller, M. E., 2015, Evaluating rehabilitation efforts following the Milford Flat Fire: successes, failures, and controlling factors: Ecosphere, v. 6, no. 5, p. 1-33.

Elith, J., Kearney, M., and Phillips, S., 2010, The art of modelling range-shifting species: Methods in Ecology and Evolution, v. 1, no. 4, p. 330-342.

ESRI, 2014, ArcGIS 10.3: Redlands, CA, Environmental Systems Research Institute.

Fick, S., Decker, C., Duniway, M. C., and Miller, M. E., 2016, Small-scale barriers mitigate desertification processes and enhance plant recruitment in a degraded semi-arid grassland.: Ecosphere, v. In Press.

Flagg, C. B., Neff, J. C., Reynolds, R. L., and Belnap, J., 2014, Spatial and temporal patterns of dust emissions (2004-2012) in semi-arid landscapes, southeastern Utah, USA: Aeolian Research, v. 15, p. 31-43.

Gao, B.-C., 1996, NDWI-A normalized difference water index for remote sensing of vegetation liquid water from space: Remote sensing of environment, v. 58, no. 3, p. 257-266.

Gesch, D. B., 2007, The National Elevation Dataset, in Maune, D., ed., Digital Elevation Model Technologies and Applications: The DEM Users Manual, American Society for Photogrammetry and Remote Sensing, p. 99-118.

Gesch, D. B., Oimoen, M., Greenless, S., Nelson, C., Steuck, M., and Tyler, D., 2002, The National Elevation Dataset: Photogrammetric Engineering and Remote Sensing, v. 68, no. 1, p. 5-11.

GO-TECH. 2015, New Mexico Oil and Gas Wells (http://octane.nmt.edu/gotech/Petroleum_Data/allwells_zip/AllWells.zip).

Goirán, S. B., Aranibar, J. N., and Gomez, M. L., 2012, Heterogeneous spatial distribution of traditional livestock settlements and their effects on vegetation cover in arid groundwater coupled ecosystems in the Monte desert (Argentina): Journal of Arid Environments, v. 87, p. 188-197.

Gremer, J. R., Bradford, J. B., Munson, S. M., and Duniway, M. C., 2015, Desert grassland responses to climate and soil moisture suggest divergent vulnerabilities across the southwestern US: Global change biology.

Grunwald, S., Thompson, J. A., and Boettinger, J. L., 2011, Digital Soil Mapping and Modeling at Continental Scales: Finding Solutions for Global Issues: Soil Science Society of America Journal, v. 75, no. 4, p. 1201-1213.

Guisan, A., and Zimmermann, N. E., 2000, Predictive habitat distribution models in ecology: Ecological modelling, v. 135 , no. 2 , p. 147-186.

Gunderson, L. H., 2000, Ecological resilience--in theory and application: Annual review of ecology and systematics, p. 425-439.

Hagen, S. C., Heilman, P., Marsett, R., Torbick, N., Salas, W., Van Ravensway, J., and Qi, J., 2012, Mapping total vegetation cover across western rangelands with moderate-resolution imaging spectroradiometer data: Rangeland Ecology \& Management, v. 65, no. 5, p. 456-467. 
Hereford, R., and Webb, R. H., 1992, Historic variation of warm-season rainfall, southern Colorado Plateau, southwestern USA: Climatic Change, v. 22, no. 3, p. 239-256.

Hereford, R., Webb, R. H., and Graham, S., 2002, Precipitation history of the Colorado Plateau region, 1900-2000, US Department of the Interior, US Geological Survey.

Hilker, T., Lyapustin, A. I., Tucker, C. J., Hall, F. G., Myneni, R. B., Wang, Y., Bi, J., de Moura, Y. M., and Sellers, P. J., 2014, Vegetation dynamics and rainfall sensitivity of the Amazon: Proceedings of the National Academy of Sciences, v. 111, no. 45, p. 16041-16046.

Homer, C., Dewitz, J., Yang, L., Jin, S., Danielson, P., Xian, G., Coulston, J., Herold, N., Wickham, J., and Megown, K., 2015, Completion of the 2011 National Land Cover Database for the Conterminous United States \&\#8211; Representing a Decade of Land Cover Change Information: Photogrammetric Engineering \& Remote Sensing, v. 81, no. 5, p. 345-354.

Huete, A. R., 1988, A soil-adjusted vegetation index (SAVI): Remote sensing of environment, v. 25, no. 3, p. 295-309.

Hyyppä, J., Hyyppä, H., Inkinen, M., Engdahl, M., Linko, S., and Zhu, Y.-H., 2000, Accuracy comparison of various remote sensing data sources in the retrieval of forest stand attributes: Forest Ecology and Management, v. 128, no. 1, p. 109-120.

Jenny, H., 1941, Factors of Soil Formation, New York, New York, McGraw-Hill.

Jenny, H., 1961, Derivation of state factor equations of soils and ecosystems: Soil Science Society of America Journal, v. 25, no. 5, p. 385-388.

Jenny, H., 1980, ECOLOGICAL STUDIES ANALYSIS AND SYNTHESIS VOL. 37. THE SOIL RESOURCE ORIGIN AND BEHAVIOR, Jenny, H. Ecological Studies: Analysis and Synthesis, Vol. 37. The Soil Resource: Origin and Behavior. Xxi+377p. Springer-Verlag: New York, N.Y., USA; Berlin, West Germany. Illus. Maps, p. XXI+377P-XXI+377P.

Jones, N. F., Pejchar, L., and Kiesecker, J. M., 2015, The Energy Footprint: How Oil, Natural Gas, and Wind Energy Affect Land for Biodiversity and the Flow of Ecosystem Services: BioScience, p. biu224.

Kendall, M. G., 1938, A NEW MEASURE OF RANK CORRELATION: Biometrika, v. 30, no. 1-2, p. 81-93.

Kokaly, R. F., 2011, Detecting Cheatgrass on the Colorado Plateau using Landsat data: A tutorial for the DESI software: US Geological Survey, 2331-1258.

Kruskal, W. H., and Wallis, W. A., 1952, Use of Ranks in One-Criterion Variance Analysis: Journal of the American Statistical Association, v. 47, no. 260, p. 583-621.

Landis, J. R., and Koch, G. G., 1977, The measurement of observer agreement for categorical data: biometrics, p. 159-174.

Li, J., Okin, G. S., Skiles, S. M., and Painter, T. H., 2013, Relating variation of dust on snow to bare soil dynamics in the western United States: Environmental Research Letters, v. 8, no. 4, p. 044054.

Liaw, A., \& Wiener, M., 2002, Classification and Regression by randomForest. R news, 2, 18-22

Lim, K., Treitz, P., Wulder, M., St-Onge, B., and Flood, M., 2003, LiDAR remote sensing of forest structure: Progress in physical geography, v. 27, no. 1, p. 88-106.

Lowry, J., Ramsey, R. D., Thomas, K., Schrupp, D., Sajwaj, T., Kirby, J., Waller, E., Schrader, S., Falzarano, S., Langs, L., Manis, G., Wallace, C., Schulz, K., Comer, P., Pohs, K., Rieth, W., Velasquez, C., Wolk, B., Kepner, W., Boykin, K., O'Brien, L., Bradford, D., Thompson, B., and Prior-Magee, J., 2007, Mapping moderate-scale land-cover over very large geographic areas within a collaborative framework: A case study of the Southwest Regional Gap Analysis Project (SWReGAP): Remote Sensing of Environment, v. 108, no. 1, p. 59-73.

Lunetta, K.L., Hayward, L.B., Segal, J., \& Van Eerdewegh, P. (2004). Screening large-scale association study data: exploiting interactions using random forests. BMC genetics, 5, 1

MacMillan, R. A., Moon, D. E., and Coupé, R. A., 2007, Automated predictive ecological mapping in a Forest Region of B.C., Canada, 2001-2005: Geoderma, v. 140, no. 4, p. 353-373. 
Maestre, F. T., Salguero-Gómez, R., and Quero, J. L., 2012, It is getting hotter in here: determining and projecting the impacts of global environmental change on drylands: Philosophical Transactions of the Royal Society of London B: Biological Sciences, v. 367, no. 1606, p. 3062-3075.

Marsett, R. C., Qi, J., Heilman, P., Biedenbender, S. H., Watson, M. C., Amer, S., Weltz, M., Goodrich, D., and Marsett, R., 2006, Remote sensing for grassland management in the arid southwest: Rangeland Ecology \& Management, v. 59, no. 5, p. 530-540.

McBratney, A. B., Santos, M. L. M., and Minasny, B., 2003, On digital soil mapping: Geoderma, v. 117, no. 1-2, p. 3-52.

Miller, M. E., Bowker, M. A., Reynolds, R. L., and Goldstein, H. L., 2012, Post-fire land treatments and wind erosion-lessons from the Milford Flat Fire, UT, USA: Aeolian Research, v. 7, p. 29-44.

Minnick, T. J., and Alward, R. D., 2015, Plant-soil feedbacks and the partial recovery of soil spatial patterns on abandoned well pads in a sagebrush shrubland: Ecological Applications, v. 25, no. 1, p. 3-10.

Mulder, V. L., Lacoste, M., Richer-de-Forges, A. C., and Arrouays, D., 2016, GlobalSoilMap France: Highresolution spatial modelling the soils of France up to two meter depth: Science of The Total Environment.

Nauman, T., and Duniway, M. C., 2016, The Automated Reference Toolset (ART): A soil-geomorphic ecological potential matching algorithm: Soil Science Society of America Journal.

Neff, J. C., Ballantyne, A. P., Farmer, G. L., Mahowald, N. M., Conroy, J. L., Landry, C. C., Overpeck, J. T., Painter, T. H., Lawrence, C. R., and Reynolds, R. L., 2008, Increasing eolian dust deposition in the western United States linked to human activity: Nature Geosci, v. 1, no. 3, p. 189-195.

Norton, J. B., Monaco, T. A., Norton, J. M., Johnson, D. A., and Jones, T. A., 2004, Soil morphology and organic matter dynamics under cheatgrass and sagebrush-steppe plant communities: Journal of arid Environments, v. 57, no. 4, p. 445-466.

NREL, 2015, Wind Data - 50m height (http://www.nrel.gov/gis/data_wind.html).

Omernik, J., and Griffith, G., 2014, Ecoregions of the Conterminous United States: Evolution of a Hierarchical Spatial Framework: Environmental Management, v. 54, no. 6, p. 1249-1266.

Painter, T. H., Deems, J. S., Belnap, J., Hamlet, A. F., Landry, C. C., and Udall, B., 2010, Response of Colorado River runoff to dust radiative forcing in snow: Proceedings of the National Academy of Sciences, v. 107, no. 40, p. 17125-17130.

Pedroni, P. M., Jaramillo, H., Torres, C., Navarrete, Z. H., Bernal-Ramirez, J., and Reed, T., 2013, A partnership approach to addressing applied ecological research needs of an oil and gas business: Journal of Applied Ecology, v. 50, no. 3, p. 539-543.

Peters, J., Villarreal, M. L., Munson, S. M., and Thoma, D., 2015, Assessing long-term vegetation change in dryland national parks using remote sensing and plot-based monitoring data: Oakland, CA, George Wright Society.

Prism Climate Group. 2010, 30-yr Normals.

Pyke, D. A., Herrick, J. E., Shaver, P., and Pellant, M., 2002, Rangeland health attributes and indicators for qualitative assessment: Journal of range management, p. 584-597.

Qi, J., Marsett, R., Heilman, P., Bieden-bender, S., Moran, S., Goodrich, D., and Weltz, M., 2002, RANGES improves satellite-based information and land cover assessments in southwest United States: Eos, Transactions American Geophysical Union, v. 83, no. 51, p. 601-606.

$R$ Core Development Team. 2008. R: A language and environment for statistical computing. $R$ Foundation for Statistical Computing, Vienna, Austria.

Rodriguez, E., Morris, C.S., \& Belz, J.E., 2006, A global assessment of the SRTM performance. Photogrammetric Engineering \& Remote Sensing, 72, 249-260

Schmidt, J., and Hewitt, A., 2004, Fuzzy land element classification from DTMs based on geometry and terrain position: Geoderma, v. 121, no. 3-4, p. 243-256. 
Schwinning, S., Belnap, J., Bowling, D. R., and Ehleringer, J. R., 2008, Sensitivity of the Colorado Plateau to change: climate, ecosystems, and society: Ecology and Society, v. 13, no. 2, p. 28.

Scull, P., Franklin, J., Chadwick, O. A., and McArthur, D., 2003, Predictive soil mapping: a review: Progress in Physical Geography, v. 27, no. 2, p. 171-197.

Seager, R., and Vecchi, G. A., 2010, Greenhouse warming and the 21st century hydroclimate of southwestern North America: Proceedings of the National Academy of Sciences, v. 107, no. 50, p. 21277-21282.

SITLA-BLM, 2015, Land Ownership (UT) (http://gis.utah.gov/data/sgidcadastre/landownership/).

Society for Ecological Restoration. 2004, International Primer on Ecological Restoration: http://www.ser.org/resources/resources-detail-view/ser-international-primer-on-ecologicalrestoration., Volume 2014.

Soil Survey Staff, 2010, Keys to Soil Taxonomy, in Service, U.-N. R. C., ed.: Washington, DC.

Tarboton, D. G., 1997, A new method for the determination of flow directions and upslope areas in grid digital elevation models: Water Resources Research, v. 33, no. 2, p. 309-319.

Team, G. E. E., 2015, Google Earth Engine: A planetary-scale geo-spatial analysis platform (https://earthengine.google.com).

Team, R. D. C., 2008, R: A language and environment for statistical computing.: Vienna, Austria, R Foundation for Statistical Computing.

Therneau, T. M., Atkinson, B., and Ripley, B., 2010, rpart: Recursive partitioning: R package version, v. 3, no. 3.8.

Thoma, D. P., Munson, S. M., Irvine, K. M., Witwicki, D. L., and Bunting, E. L., 2016, Semi-arid vegetation response to antecedent climate and water balance windows: Applied Vegetation Science, v. 19, no. 3, p. 413-429.

Thornthwaite, C. W., 1948, An approach toward a rational classification of climate: Geographical review, v. 38 , no. 1 , p. 55-94.

UAGRC. 2015a, Oil and Gas Wells (http://gis.utah.gov/data/energy/oil-gas/).

UAGRC, 2015b, Roads and Highway System (http://gis.utah.gov/data/sgid-transportation/roadssystem/).

USCB-GD, 2015, 2015 TIGER/Line Shapefiles: Roads (https://www.census.gov/geo/mapsdata/data/tiger-line.html).

USDA-NRCS, 2014, National Ecological Site Handbook.

USDI-BLM, AIM Terrestrial Monitoring Data., in Center, B. N. O., ed.: Denver, CO. http://www.landscape.blm.gov/geoportal/rest/find/document?searchText=isPartOf\%3AAIM\&c ontentType=downloadableData\&start=1\&max=10\&f=searchpage, Accessed 8/25/2016.

USDI-BLM, and USDA, 2007, Surface Operating Standards and Guidelines for Oil and Gas Exploration and Development, Volume BLM/WO/ST-06/021+3071/REV 07: Denver, Colorado, Bureau of Land Management.

USGS, 2016, Using the USGS Landsat 8 Product (http://landsat.usgs.gov/Landsat8_Using_Product.php).

Villarreal, M. L., Norman, L. M., Buckley, S., Wallace, C. S. A., and Coe, M. A., 2016, Multi-index time series monitoring of drought and fire effects on desert grasslands: Remote Sensing of Environment, v. 183, p. 186-197.

Warner, B., and Shapiro, J., 2013, Fractured, fragmented federalism: A study in fracking regulatory policy: Publius: The Journal of Federalism, p. pjt014.

Webb, R. H., 2002, Recovery of severely compacted soils in the Mojave Desert, California, USA: Arid Land Research and Management, v. 16, no. 3, p. 291-305.

Witwicki, D.L., Munson, S.M., \& Thoma, D.P. 2016. Effects of climate and water balance across grasslands of varying C3 and C4 grass cover. Ecosphere, 7, e01577 
853 Yang, X., Chapman, G. A., Gray, J. M., and Young, M. A., 2007, Delineating soil landscape facets from 854 digital elevation models using compound topographic index in a geographic information system: Australian Journal of Soil Research, v. 45, no. 8, p. 569-576.

856

857 
9 Appendix A. Variables used in DART for local topographic (TOPO) and Landsat geologic (LS) classification as well as screening (SCR) of developed areas (adapted from Nauman and Duniway, 2016).

\section{Source Variable Description}

\begin{tabular}{|c|c|c|}
\hline & NWNESS & index from 1 to -1 of how northwest (1) or southeast (-1) a site faces \\
\hline & EASTNESS & index from 1 to -1 of how east (1) or west (-1) a site faces \\
\hline & SOUTHNESS & index from 1 to -1 of how south (1) or north $(-1)$ a site faces \\
\hline & NENESS & index from 1 to -1 of how northeast (1) or southwest (-1) a site faces \\
\hline & ELEVm & elevation in meters \\
\hline & TCURVLP3 & curvature perpendicular to the slope direction (Conrad and Wichmann, 2011) \\
\hline National & PCURVLP3 & curvature parallel to the slope direction (Conrad and Wichmann, 2011) \\
\hline Dataset & PROTINDEX & Protection Index of surrounding topography (Conrad and Wichmann, 2011) \\
\hline 30-meter & SLPLP3 & slope gradient in degrees \\
\hline resolution & MRRTF & multiple resolution ridgetop flatness index (Conrad and Wichmann, 2011) \\
\hline (TOPO) & MRVBF & multiple resolution valley bottom flatness index (Conrad and Wichmann, 2011) \\
\hline & TWILP3 & topographic wetness index, also called compound topographic index \\
\hline & CALP3 & upstream contributing area (Using Dinf, Conrad and Wichmann, 2011; Tarboton, 1997) \\
\hline & $\begin{array}{c}\text { RELHT } \\
(1,2, \mathrm{n} . .128)\end{array}$ & $\begin{array}{l}\text { Height of cell above the local minimum elevation in n-pixel radius } \\
\mathrm{n}=1,2,4,8,16,32,64,128 \text { (By comparing to Focal Statistics minimum tool, ESRI, 2014) }\end{array}$ \\
\hline & $\begin{array}{l}\text { RELMNHT } \\
(1,2, \mathrm{n} . .128)\end{array}$ & $\begin{array}{l}\text { Height of cell above the local mean elevation in n-pixel radius } \\
\mathrm{n}=1,2,4,8,16,32,64,128 \text { (By comparing to Focal Statistics mean tool, ESRI, 2014) }\end{array}$ \\
\hline & LFELEMS & $\begin{array}{l}\text { Landform classification system using DEM: landform elements (Conrad and Wichmann, } \\
\text { 2011; Schmidt and Hewitt, 2004) }\end{array}$ \\
\hline $\begin{array}{l}\text { NREL Wind } \\
\text { (TOPO) }\end{array}$ & wind & Wind potential at 50m height from NREL: (NREL, 2015). \\
\hline $\begin{array}{l}\text { Landsat } 8 \text { ND } \\
\text { ratios (LS) }\end{array}$ & $\begin{array}{l}\text { redbluend } \\
\text { redgreennd } \\
\text { swir1swir2nd }\end{array}$ & red/blue, red/green, swir1/swir2 as normalized difference indices. \\
\hline $\begin{array}{l}\text { NLCD } \\
(\mathrm{SCR})\end{array}$ & NLCDcl & National Land Cover Database (Homer et al., 2015) \\
\hline $\begin{array}{l}\text { SWREGAP } \\
\text { (SCR) }\end{array}$ & swregap_nm & SW vegetation and landcover map (Lowry et al., 2007) \\
\hline
\end{tabular}


86310 Appendix B. Google Earth Engine Code for SATVI creation.

864 var Lfact = .9;

865 var jsonstring=null;

866 var cloudshadow $=$ ee.Geometry.Point $([-108.7564,36.1445])$;

867 var hazyarea = ee.Geometry.Point([-109.482879,39.3791604]);

868

869 function calc_satvi(image_in, swir1_in, swir2_in)\{

870 return image_in.expression('((1.9* (swir1 - red)) / (swir1 + red + .9)) - swir2/2',

871 \{'swir1' : swir1_in, 'swir2': swir2_in, 'red': image_in.select('B4')\});

$872\}$

873

874 function export_image(image_in, task_name_in) \{

875 Export.image(image_in, task_name_in,

876 \{driveFileNamePrefix: 'UT'+task_name_in, scale: 30, maxPixels: 1400000000, region: jsonstring\});

$877\}$

878 function Mosaic() \{

879 // Define boundary of clip extent

880 var polygon = ee.FeatureCollection('ft:1xFxk4nOLf5q4D04ibV9SUdPvf1jLVp2HTKz4rqDX');

881 // Cloud Index Value

$882 \quad / / 61440=$ Cloudy (high probability) Cirrus

$883 / / 53248=$ Cloudy (high probability) Non-Cirrus

$884 \quad / / 28672=$ Cloudy (low probability) Cirrus

885 var collectionnames=['LANDSAT/LC8_SR','LC8_L1T_TOA'];

886 // Change later to scenes from May thru July 2014

887 var startDate = new Date('5/15/2014');

888 var endDate $=$ new Date('9/30/2014');

889 var collection = ee.ImageCollection(collectionnames[1])

890 .filterDate(startDate, endDate);

891 var srcollection $=$ ee.ImageCollection(collectionnames[0]) 
892 .filterDate(startDate, endDate);

893 // From Noel at Google

894 var maskL8 = function(image) \{

895 var quality = image.select( 'BQA' );

896 var cloud01 = quality.eq(61440);

897 var cloud02 = quality.eq(53248);

898 var cloud03 = quality.eq(28672);

899 var maskedlmage = image.mask().and(cloud01.or(cloud02).or(cloud03).not());

900 return image.mask(maskedlmage);

$901\}$

902

903 var VizParams $=\{\min : 0, \max : 0.7$, 'bands':'B4,B3,B2' $\}$;

904 centerMap(-109.65,38.64);

905

906 // Select median pixels and clip

907 var image2 = collection.median().clip(polygon);

908 Map.addLayer(polygon, \{color: 'FFFF00'\}, 'study area');

909 Map.setCenter(-111,38,7);

910 var collectionMasked = collection $\cdot$ map $($ maskL8);

911 var image3 = collectionMasked.median().clip(polygon);

912 addToMap(image3, VizParams, "With Cloud Mask",true);

913 var swir2 = image3.select('B7');

914 var swir1 = image3.select('B6');

915 var satvi = calc_satvi(image3, swir1, swir2);

916 var satvi_10k = satvi.multiply(10000)

917 var satvi_int = satvi_10k.round();

918 Map.addLayer(satvi_int, \{min:-10000, max:10000\}, 'satvi_int');

919 export_image(satvi_int, 'I8satvi_int');

920 
$921\} / /$ end of function

922 Mosaic();

923

924 
11 Appendix C. Southwest ReGAP generalized class (regap_veg) look-up table summarizing how ReGAP classes were simplified for use in trend analysis

\begin{tabular}{|c|c|c|}
\hline Value & SW ReGAP Label & Generalized Class \\
\hline 5 & Rocky Mountain Cliff and Canyon & Canyons \\
\hline 9 & Colorado Plateau Mixed Bedrock Canyon and Tableland & Canyons \\
\hline 10 & Inter-Mountain Basins Shale Badland & Badland \\
\hline 11 & Inter-Mountain Basins Active and Stabilized Dune & Dunes \\
\hline 36 & Colorado Plateau Pinyon-Juniper Woodland & Pinon-Juniper (PJ) \\
\hline 40 & Inter-Mountain Basins Mat Saltbush Shrubland & Saline Shrubland \\
\hline 46 & Colorado Plateau Pinyon-Juniper Shrubland & Pinon-Juniper (PJ) \\
\hline 48 & Inter-Mountain Basins Big Sagebrush Shrubland & Sagebrush \\
\hline 50 & Colorado Plateau Mixed Low Sagebrush Shrubland & Sagebrush \\
\hline 53 & Colorado Plateau Blackbrush-Mormon-tea Shrubland & Blackbrush \\
\hline 58 & Inter-Mountain Basins Mixed Salt Desert Scrub & Saline Shrubland \\
\hline 62 & Inter-Mountain Basins Montane Sagebrush Steppe & Sagebrush \\
\hline 67 & Inter-Mountain Basins Semi-Desert Shrub Steppe & Shrubland \\
\hline 76 & Inter-Mountain Basins Semi-Desert Grassland & Grassland \\
\hline 79 & Rocky Mountain Lower Montane Riparian Woodland and Shrubland & Riparian \\
\hline 82 & Inter-Mountain Basins Greasewood Flat & Saline Shrubland \\
\hline 108 & Southern Colorado Plateau Sand Shrubland & Shrubland \\
\hline 111 & Developed, Open Space - Low Intensity & Disturbed \\
\hline 114 & Agriculture & Agriculture \\
\hline 118 & Invasive Southwest Riparian Woodland and Shrubland & Riparian \\
\hline 121 & Invasive Annual Grassland & Grassland \\
\hline 124 & Recently Chained Pinyon-Juniper Areas & Pinon-Juniper (PJ) \\
\hline 125 & Disturbed, Oil well & Disturbed \\
\hline 71 & Southern Rocky Mountain Montane-Subalpine Grassland & subalpine grassland \\
\hline 42 & Rocky Mountain Lower Montane-Foothill Shrubland & Shrubland \\
\hline 64 & Inter-Mountain Basins Juniper Savanna & Pinon-Juniper (PJ) \\
\hline 122 & Invasive Annual and Biennial Forbland & invaded \\
\hline 41 & Rocky Mountain Gambel Oak-Mixed Montane Shrubland & Oak \\
\hline 116 & Recently Burned & Disturbed \\
\hline 22 & Rocky Mountain Aspen Forest and Woodland & Aspen \\
\hline
\end{tabular}


12 Appendix D. Classification Tree plot showing splits and node class memberships. All rules in plot define which cases move to the left branch of each node, the remaining cases (inverse of rule) move to the right branch. Numbers at each node and leaf (eg. 134/81) indicate high/low membership in training set. Categorical variable codes used in tree plot are defined in embedded tables. See Table 1 for more specific variable definitions. The 'low' class indicates lower recovery quantile $(<0.22)$; 'high' indicates better recovery quantile $(>0.22)$

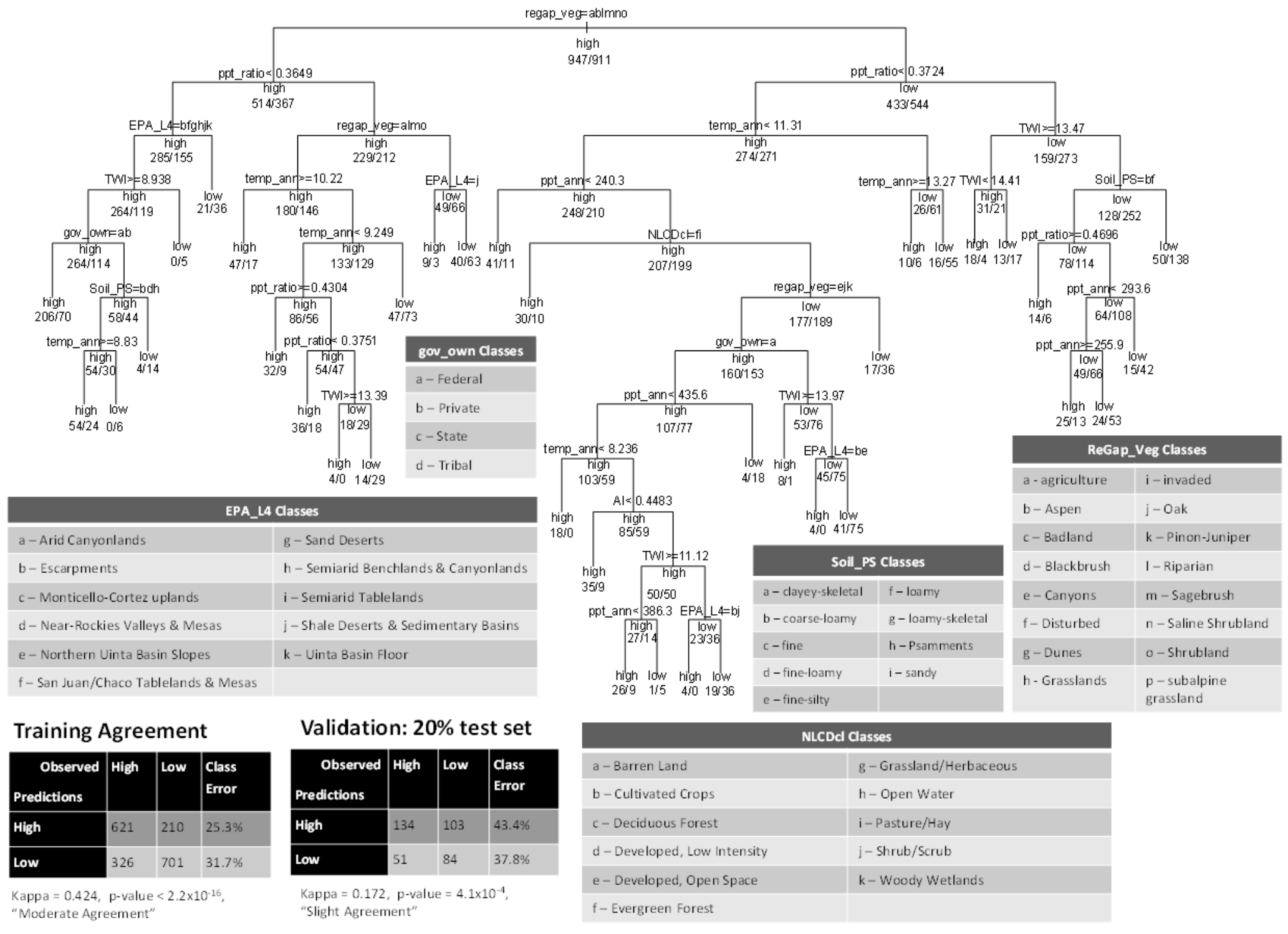

\begin{tabular}{|l|l|}
\hline e- Developed, Open Space & $k$-Woody Wetlands \\
\hline $\mathbf{f}-$ Evergreen Forest & \\
\hline
\end{tabular}




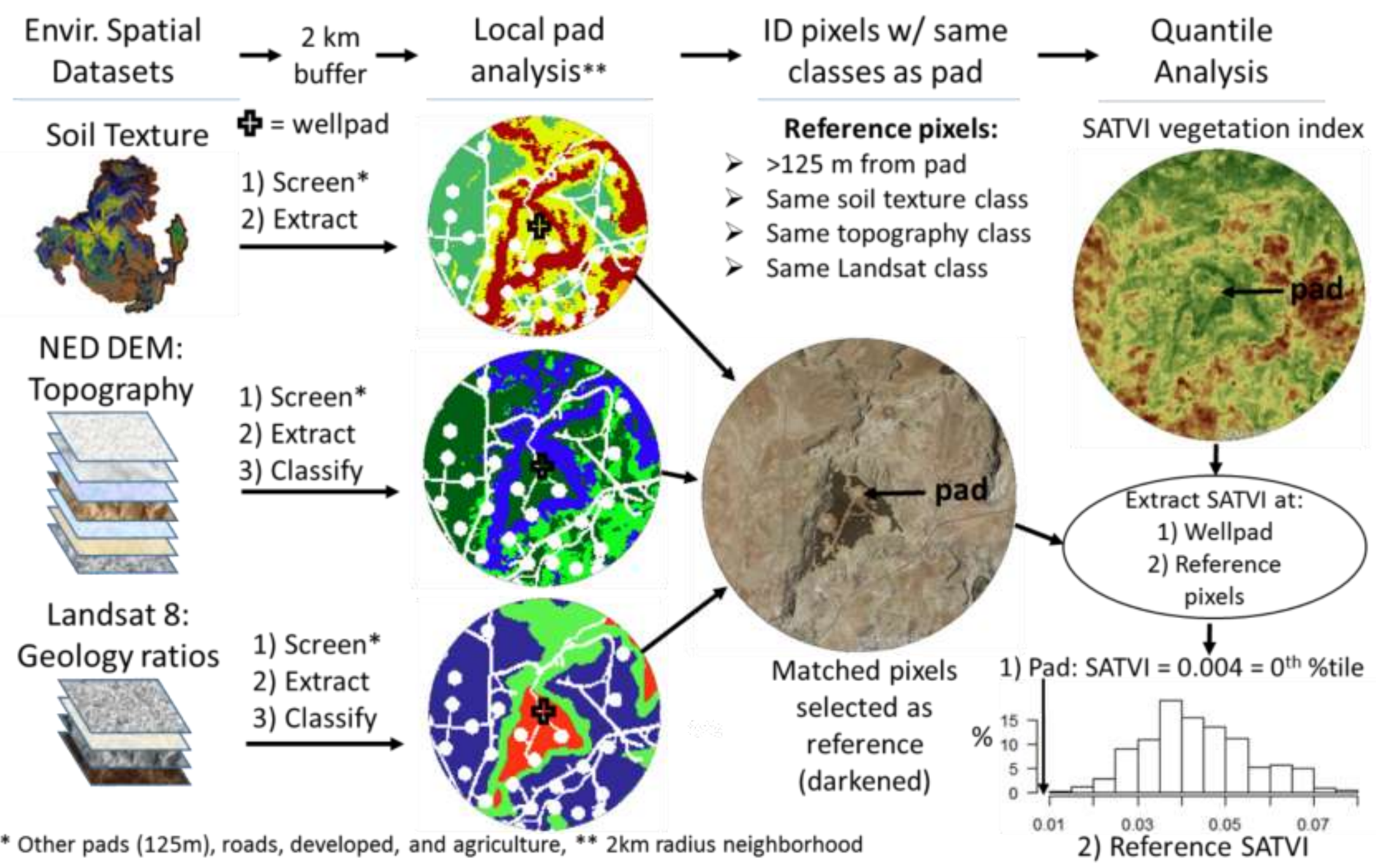

